\title{
Predictors of Urban Variable Source Area: A Cross-Section Analysis of Urbanized Catchments in the United States
}

\begin{tabular}{|r|l|}
\hline Journal: & Hydrological Processes \\
\hline Manuscript ID & HYP-16-0036.R2 \\
\hline Wiley - Manuscript type: & Research Article \\
\hline Date Submitted by the Author: & n/a \\
\hline Complete List of Authors: & Lim, Theodore; University of Pennsylvania, City and Regional Planning \\
\hline Keywords: & $\begin{array}{l}\text { Rainfall-runoff ratio, Variable Source Area (VSA), Effective Impervious Area } \\
\text { (EIA), urbanized watersheds, regression analysis }\end{array}$ \\
\hline
\end{tabular}

\section{SCHOLARONE ${ }^{m}$}

Manuscripts

An edited version of this paper was published in Hydrological Processes. Copyright (2016) Wiley. The article can be accessed at: http:/doi.org/10.1080/09640568.2017.1350146

Suggested citation:

Lim, Theodore Chao. 2016. “Predictors of Urban Variable Source Area: A Cross-Section Analysis of Urbanized Catchments in the United States." Hydrological Processes, June, 4799-4814. https://doi.org/10.1002/hyp.10943. 
Predictors of Urban Variable Source Area

LIM

\title{
TITLE
}

Predictors of Urban Variable Source Area: A Cross-Section Analysis of Urbanized Catchments in the United States

\section{AUTHOR NAMES AND AFFILIATIONS}

\author{
THEODORE CHAO LIM ${ }^{a^{*}}$
}

a. University of Pennsylvania, Department of City Planning. 127 Meyerson Hall, 210 South $34^{\text {th }}$ Street, Philadelphia, PA 19104

*Corresponding author. tlim@design.upenn.edu 
Predictors of Urban Variable Source Area

\title{
RUNNING HEAD
}

\author{
Predictors of Urban Variable Source Area
}

\begin{abstract}
Many studies have empirically confirmed the relationship between urbanization and changes to the hydrologic cycle and degraded aquatic habitats. While much of the literature focuses on extent and configuration of impervious area as a causal determinant of degradation, in this article I do not attribute causes of decreased watershed storage on impervious area a priori. Rather, adapting the concept of variable source area (VSA) and its relationship to incremental storage to the particular conditions of urbanized catchments, I develop a statistically-robust linear regression-based methodology to detect evidence of VSA-dominant response. Using the physical and meteorological characteristics of the catchments as explanatory variables, I then use logistic regression to statistically analyze significant predictors of the VSA classification. I find that the strongest predictor of VSA-type response is the percent of undeveloped area in the catchment. Characteristics of developed areas, including total impervious area, percent developed open space, and the type of drainage infrastructure do not add to the explanatory power of undeveloped land in predicting VSA-type response. Within only developed areas, I find that total impervious area (TIA) and percent developed open space both decrease the odds of a catchment exhibiting evidence of VSA-type response and the effect of developed open space is more similar to that of TIA than undeveloped land in predicting VSA response.
\end{abstract}


Predictors of Urban Variable Source Area

Different types of stormwater management infrastructure, including combined sewer systems (CSS) and infiltration, retention, and detention infrastructure are not found to have strong statistically significant effects on probability of VSA-type response. VSA-type response is also found to be stronger during the growing season than the dormant season. These findings are consistent across a national cross-section of urbanized watersheds, a higher resolution dataset of Baltimore Metropolitan Area watersheds, and a subsample of watersheds confirmed not to be served by (CSS).

\section{KEYWORDS}

Rainfall-runoff ratio; Variable Source Area (VSA); Effective Impervious Area (EIA); urbanized watersheds; regression analysis

\section{INTRODUCTION AND BACKGROUND}

Research has long shown the link between urbanization and degraded water quality and aquatic habitat (Hammer, 1972; Hatt et al., 2004; Newall and Walsh, 2005). For managers of urbanizing watersheds, one key indicator of negative hydrological change has been impervious surface area. Instead of subsurface flows that are typically the dominant response to rain events in humid catchments, the hydrologic response in urbanized watersheds becomes dominated by surface runoff (Leopold, 1968; Arnold and Gibbons, 1996). Increased surface runoff occurs when impervious surfaces in the form of roofs, parking lots, roads and sidewalks prevent precipitation from infiltrating to the underlying soil. The result is a "flashier" runoff-response, 
which leads to flooding and erosion and sedimentation of natural water bodies (Booth and Jackson, 1997; McBride and Booth, 2005).

Impervious surface area has emerged as a key indicator of impaired aquatic habitat for watershed managers and urban planners for its ease of conceptual understanding, but research has shown that impervious surface area alone is not sufficient for understanding underlying mechanisms of hydrological response and degradation (Harbor, 1994; Brabec, 2002; Shuster et al., 2005). One key distinction when trying to quantify impervious surface is the functional difference between Total Impervious Area (TIA) and Effective Impervious Area (EIA). Underlying the concept of EIA is the idea that degree of connectivity of impervious surface area is important in addition to the total magnitude of impervious area (McBride and Booth, 2005; Shuster et al., 2005; Alberti and Booth, 2007; Moglen and Kim, 2007). Emphasis on hydraulic connectivity implies that pervious surfaces could also function similarly to impervious surfaces and hydrologic response is dependent on antecedent moisture of underlying soils, slope and connectivity to impervious surfaces. Alternatively, impervious surfaces that are not hydraulically connected to the drainage network may not be considered EIA. This latter concept is the principle behind run-on infiltration stormwater management techniques in urbanized areas, which aim to "disconnect" impervious areas, reduce peak flows and volumes, and increase baseflows to local streams (Miles and Band, 2015).

Researchers have approached quantifying EIA from TIA in different ways, including using empirical conversion factors, field surveys, and sensitivity analyses, but there is general 
agreement that EIA, rather than TIA more closely represents the physical process of hydrological impact on flow regimes (Alley and Veenhuis, 1983; Dinicola, 1990; Booth and Jackson, 1997; Brabec, 2002; Shuster et al., 2005; Knighton et al., 2013; Palla and Gnecco, 2015). Hydraulic connectivity has not only been shown to be one of the most sensitive parameters in urban hydrological modeling, resulting in modeled peak discharge variations of up to $265 \%$ in some cases (Lee and Heaney, 2003). It is also among the parameters estimated with the most uncertainty in urban hydrological modeling (Moglen and Kim, 2007; Knighton et al., 2013). Others have suggested that overemphasis on connectivity of impervious area (EIA vs TIA) detracts from important changes to soil porosity, vegetation, imported water and other water infrastructure that urbanization has on hydrologic response and catchment water balance (Brandes et al., 2005; Meierdiercks et al., 2010a; Hamel et al., 2013).

In this study, I do not assume impervious area as the dominant causal factor for flashy hydrologic response. Instead, I develop a robust statistical methodology to classify urban catchments into two groups: those dominated by VSA-type response, and those dominated by Hortonian-type response. Based on the classification, I address the following questions:

1.) How does undeveloped land compare to land development variables in explaining the presence of VSA-response?

2.) How does a higher fraction of developed (low density) open area in urban areas influence VSA? 
3.) How does stormwater management infrastructure, such as proximity to a combined sewer outfall, or presence of detention/retention-based stormwater management guidelines affect the probability of VSA-response?

This study contributes to the existing literature by providing empirical evidence of the development-specific characteristics associated with VSA-type response using a cross-section analysis of 119 unique urbanized catchments.

\section{URBAN VARIABLE SOURCE AREA}

In the Hortonian model of runoff generation, runoff occurs when infiltration rates are exceeded by rainfall intensities. This differs from runoff generation in humid regions, which occurs by subsurface storm flow and saturation excess overland flow (Dunne and Black, 1970; Dunne et al., 1975; Dunne, 1978). Consideration of antecedent soil moisture and differential contraction of saturated areas between storm events led to the "variable source area" (VSA) concept of runoff generation. VSA emerged as an important model describing event-to-event, non-constant runoff contributing areas in undisturbed humid regions (USFS, 1961; TVA, 1965; Hewlett and Hibbert, 1967; Dunne et al., 1975).

Subsequent empirical research has shown that site-specific conditions such as high soil conductivity, steep slopes, mid-slope or downslope positions within the watershed and seasonality affect presence of the VSA condition (McGlynn and McDonnell, 2003; Jencso et al., 2009). In mountainous, alpine forested and agricultural catchments, runoff is first generated in 
riparian zones, and riparian-hillslope connectivity increases under wetter conditions (McGlynn et al., 2004; Ocampo et al., 2006; James and Roulet, 2007; Wenninger et al., 2008). Monitoring patterns of soil moisture spatial extent has shown a clear thresholding relationship between antecedent wetness and rainfall and storm runoff (Detty and McGuire, 2010; Penna et al., 2011). Event-based rainfall runoff ratios also support threshold relations in subsurface stormflow and that subsurface flow is a dominant source of runoff (Tromp-van Meerveld and McDonnell, 2006). While the VSA model has been called into question for its ability to apply to all situations (McDonnell, 2003), it still remains attractive for its ability to conceptualize non-constant ratios in the rainfall-runoff transformation.

In the study of urbanized catchments, land-use change and other human modifications to catchments has resulted in both better identification of specific processes and confounded sources of observed non-constant contributing area and thresholding effects. There has been significant interest in examining the effects of impervious surface area, infrastructure and developed open space associated with urbanization on increased hydraulic connectivity at the catchment scale. Placement and configuration of imperviousness within a catchment can have a significant influence on downstream response (Mejía and Moglen, 2010). Locations and configuration of conventional conveyance (Tague and Pohl-Costello, 2008; Meierdiercks et al., 2010a; Ogden et al., 2011), infiltration-based (Gobel et al., 2004; Easton et al., 2007; Miles and Band, 2015) and detention-based (Smith et al., 2015) stormwater management infrastructures 
also influence incremental connectivity in hydrologic response of a catchment under varying event depths.

Contrary to commonly held beliefs about limiting imperviousness of development in order to avoid negative changes in hydrologic regime, studies indicate that developed open space can also have limited ability to prevent flashy response. Reasons for this include the limited infiltrative capacity of compacted soils (Smith and Smith, 2015), high proportion of runoff response attributed to shallow subsurface flow under residential lawns (Wigmosta and Burges, 1997), subsurface saturation due to leaky water distribution infrastructure (Lerner, 2002), and decreased evapotranspiration associated with vegetation change (Bhaskar et al., 2015). Figure 1 shows an adaptation of the VSA to include urban run-on from impervious areas and other potential sources of impacts to soil saturation in urbanized catchments (Miles and Band, 2015). As shown in Figure 1, urban VSA response is associated with incremental connectivity of conveyance infrastructure, impervious areas, and soils and pervious areas.

[Figure 1 (a) Dunne et al.'s original conceptualization of runoff generation process and sources of variable source area. (b) Conceptualization of potential stormwater fates in low to medium density urbanized watersheds. (c) Conceptualization of runoff generation process in low to high density urbanized watershed and potential causes of observed variable source area, including infrastructure storage and leakage. (a) and (b) reproduced from Miles and Band (2015), used with permission from Wiley. ] 
Analyses of empirical rainfall-runoff relationships from urbanized catchments have revealed that for smaller storms $(<38.1 \mathrm{~mm}$ or 1.5 inches), runoff depths as a fraction of the rainfall depths correspond closely to the EIA of the catchment. However, this relationship is less reliable for larger storms (Doyle and Miller, 1980). Regression-based analyses of the relationship between rainfall and runoff depths have been used to delineate the sequentially gained hydraulic connectivity of EIA, TIA and pervious areas respectively and to estimate their proportions within the catchment area (Boyd et al., 1993, 1994; Goldshleger et al., 2012; Loperfido et al., 2014; Ebrahimian et al., 2016). Studies which examine changing ratios between rainfall depth and runoff depth within a catchment all share a common interpretation that the variable proportion of area contributing to the hydrologic response is dependent on the total depth of rainfall.

This study aims to determine the significant predictors of VSA hydrologic response across urbanized catchments using regression analysis. Previous studies suggest that both impervious surface and land development in general (including seemingly pervious areas) will result in the dominance of Hortonian flow over VSA, while lower levels of development will result in the dominance of VSA over Hortonian overland flow (Miles, 2014). In urbanized catchments with high levels of impervious surface, we expect the contributing area from these catchments to correspond to the fraction of the catchment area that is composed of impervious area. 
In VSA-dominated catchments, we expect a nonlinear relationship between rainfall and runoff. As rainfall depths increase or rainy periods are prolonged, we expect some areas within the catchment area to incrementally lose capacity to store and infiltrate precipitation as storage thresholds are exceeded. This will lead to an increasing slope in the relationship between rainfall and runoff as cumulative rainfall depths increase. It should be noted that the conceptualization presented in this work (Figure 1), departs from the Dunne VSA model in that it includes both runoff production processes (saturation excess and infiltration excess) and other factors specifically of interest in urbanized catchments that influence observable nonlinearity at discrete downstream streamflow measurement locations, such as the presence of CSS or other stormwater management infrastructure.

\section{METHODS}

Broadly, my methodology involves three steps. First, I perform hydrograph separation to create a dataset of paired event rainfall-runoff depths for each catchment in the analysis. Second, I develop a statistical methodology to detect the presence of nonlinearity in the rainfall-runoff relationship for each of the catchments, using the rainfall event data. Lastly, I use logistic regression to estimate the effects of the catchments' characteristics on VSA-type response. 
Predictors of Urban Variable Source Area

\subsection{Data}

\subsubsection{National-level datasets}

Catchments for the analysis were selected from stream gauge flow monitored by the USGS, with characteristics included in the GAGES II database. GAGES II was developed by the USGS to provide users with an exhaustive set of geospatially-specified catchment characteristics corresponding to a large number of gauged watersheds. The database includes both "reference" watersheds, which are minimally influenced by human activity, and watersheds that represent a range of hydrologic conditions including urban development intensity (Falcone et al., 2010). For a catchment in the national-level dataset to be included in this study, I used three criteria. First, the catchment had to be at least $50 \%$ developed according to the National Land Cover Dataset urban development classification. Second, the stream gauge had to be located within a 15-mile radius of an airport-based precipitation gauge having hourly data. Third, the catchment had to have at least 35 rainfall events that resulted in paired rainfall-runoff data. Stream gauge data for GAGES II catchments were downloaded from the USGS website (http://nwis.waterdata.usgs.gov/nwis/sw) using basin identification numbers and date ranges for available flow and precipitation data (Lins, 2012). Precipitation data was obtained from the National Climatic Data Center (http://www.ncdc.noaa.gov/ ). From these criteria, the study included 91 analysis catchment areas in the contiguous US (shown in Figure 2).

The catchments ranged from $50.49 \%$ developed to $99.98 \%$ developed. The median level of development was $84.37 \%$. The 30-year (1970-2000) average annual precipitation among the 
study basins ranged from $63.31 \mathrm{~cm}$ to $136.80 \mathrm{~cm}$. The drainage areas ranged from $3.70 \mathrm{~km}^{2}$ to $505.80 \mathrm{~km}^{2}$ with a median drainage area of $85.06 \mathrm{~km}^{2}$. The generalized rainfall intensities in centimeters per hour for a 2-year, 1-hour storm event ranged from $4.06 \mathrm{~cm}$ (1.6 inches) per hour to $5.59 \mathrm{~cm}$ (2.2 inches) per hour.

I added three variables to those in the GAGES II database,: (1) distance of the stream gauge location to the nearest (upstream or downstream) active combined sewer outfall; (2) whether the watershed included a community served by a CSS; and (3) a binary variable for whether the city or county in which the stream gauge was located encouraged infiltration, retention, or detention-based stormwater management practices at the time of the study. Geospatial locations of permitted outfalls were extracted from the EPA's Facility Registry Service (http://www.epa.gov/enviro/facility-registry-service-frs ) for all permitted combined sewer outfalls listed by EPA (US EPA, 2004). Promotion of stormwater management practices was determined through an internet search of the name of the city and county in which the gauge was located, followed by the terms "Stormwater Detention, Retention, Green Infrastructure, Infiltration." Locations for which informational materials were readily available were presumed to be "actively" promoting this type of decentralized infrastructure.

Because CSSs have the potential to confound the results of the VSA classification analysis, I subset the national-level dataset with gauges known to not include any combined sewer systems. Of the 91 national-level catchments, 56 were confirmed not to have CSS within 
Predictors of Urban Variable Source Area

their boundaries. This subset is hereafter referred to as the "non-CSS dataset" (shown in Figure 2).

[Figure 2. Locations of national dataset and non-CSS dataset analysis catchments]

\subsubsection{Baltimore Metropolitan Area (BMA) datasets}

The question of spatial heterogeneity in rainfall records was one of the major concerns with the analysis of the national dataset. Others have shown that especially in urbanized areas, where human activity and changes to the natural landscape influence micro-climates and local weather patterns, precipitation measured at one discrete location can vary significantly from the amount of rainfall at another nearby rain gauge (Shepherd, 2005; Smith et al., 2012). For this reason, the analyses were also performed on a dataset of Baltimore Metropolitan Area (BMA) basins for which there was HydroNEXRAD radar precipitation data available covering the entirety of the gauge's catchment area. Radar rainfall data processed by the HydroNEXRAD system was obtained at a 1 square kilometer resolution at 15-minute intervals. A multiplicative bias correction value was then used to bias correct basin average time series data for each basin for each 15-minute time period to calibrate HydroNEXRAD data to precipitation records from a diverse network of rain gauges in the Baltimore region (Smith et al., 2012). This procedure 
allowed for the use of spatial precipitation records that fell over the contributing area and should be much more accurate than discrete rain gauge data.

[Figure 3. BMA dataset gauge locations and basin boundaries]

After the time-series-averaged precipitation data was obtained for each watershed, the procedure used for pairing rainfall events with flow gauge readings was identical to that of the national dataset. Due to data limitations, only 34 watersheds over 30\% developed were left for the study (Figure 3). The watersheds ranged from 31.86\% developed to $96.87 \%$ developed. The average annual precipitation depth (from 1970-2000) ranged from $107.9 \mathrm{~cm}$ to $123.3 \mathrm{~cm}$. The drainage areas ranged from $1.20 \mathrm{~km}^{2}$ to $906.60 \mathrm{~km}^{2}$. Some watersheds that were not included in the national-level dataset because of a lack of a proximate rain gauge station were included in the Baltimore Metropolitan Area dataset, for which the more accurate radar precipitation data was available. Combined sewer outfall proximity was calculated as for the national-level dataset. Using the same internet search method as was used for the national dataset, all counties for the BMA catchments were determined to have implemented detention, retention or infiltration-based stormwater management policies, therefore the effect of this development characteristic could not be estimated through regression and it was not included in the BMA 
Predictors of Urban Variable Source Area

analysis. Between the national and BMA datasets, there were 119 unique catchments included in the study.

\subsection{Hydrograph Separation and Event Definition}

I used the R package 'EcoHydRology' to separate the hydrographs into baseflow and quickflow components (Fuka et al., 2014). By visual inspection of the hydrograph separation for a $12.7 \mathrm{~mm}$ (0.5 inches) rainfall event and a $38.1 \mathrm{~mm}$ rainfall event (1.5 inches) for a few representative watersheds, I determined that a filter parameter of 0.925 and three passes was appropriate to automate baseflow separation across the variation in my analysis catchments. Since some catchments exhibited very little response to rainfall, I defined the start and end of rainfall events from the continuous precipitation record. Events were defined as any length of time that preceded and followed by 96-hour periods of no rainfall in the precipitation record. The implicit assumption of the 96-hour dry period is that localized groundwater mounding or saturation that could contribute to VSA within a catchment would decrease in influence after that period. To capture the full quickflow component of the hydrograph in the flow record (especially in larger catchments), I added a buffer of 36 hours after the precipitation-defined end time of the event. Through separated hydrograph inspection, I confirmed that the 36- hour period was long enough to capture the quickflow response even from the larger catchments in the dataset. An example of the separation (described below) is shown in Figure 4. The time step for all hydrograph separation was 15 minutes. All flow data were available at least at this resolution. Flow data collected at a higher resolution time step were averaged to 15 minute intervals. 
For each event, precipitation depths were summed and paired with cumulative quickflows over the defined event period and normalized by dividing by the catchment area. Thus, for each analysis catchment, a set of paired rainfall-runoff depths for each event was created. An identical process was carried out for the BMA dataset, except that the source of the precipitation data was basin-averaged, bias-corrected HYDRO-NEXRAD data.

[Figure 4. Example of hydrograph separation using R package 'EcoHydRology' for the watershed in our sample with the largest drainage area, Salado Creek in San Antonio, TX (drainage area $\left.=505.8 \mathrm{~km}^{2}\right)$. The flow response to a $38.1 \mathrm{~mm}(1.5 \mathrm{inch})$ total rainfall depth is shown. The response returns to baseflow conditions within the 36-hour period.]

\subsection{Robust Statistical Detection of VSA}

Classification of catchments as having dominant VSA processes was based on the statistical detection of nonlinearity in the rainfall-runoff response of the catchment. Statistical significance of nonlinearity was determined through the estimation of the linear model:

$$
\operatorname{runoff}_{i j}=\alpha_{i}+\beta_{1 i} \operatorname{rain}_{i j}+\beta_{2 i} \exp \operatorname{rain}_{i j}+u_{i j}
$$


where rain ij $_{i}$ is the precipitation depth of each event $j$ in the time period for catchment $i$ and runoff $_{i j}$ is the runoff depth corresponding to precipitation event $j$. If the coefficient estimated for $\exp \left(\right.$ rain $\left._{i j}\right)$ was statistically significant, this indicated evidence of nonlinearity in the rainfallrunoff relationship averaged over many events. In the detection of VSA processes, I expected this nonlinearity to be positive.

One problem with the above specification is that it suffers from heteroscedasticity, or non-constant variance in the residuals of the estimated equation. While heteroscedasticity does not bias the estimates of the coefficients in a linear regression, it does result in inefficient estimates of the standard errors of the coefficient estimates. In order to correct the effects of heteroscedasticity on standard error estimates of the coefficients, I log-transformed both the rainfall and runoff data to improve residual distribution. I used the $\mathrm{R}$ package 'sandwich' to estimate robust standard errors for the coefficients of the log transformed model [1] (Zeileis, 2004). I assigned catchments as VSA-dominant if $\beta_{2}$ was significant at the $\alpha=0.05$ level, and nonVSA dominant if $\beta_{2}$ was not significant at the $\alpha=0.05$ level. The result of this part of the analysis was an assigned binary hydrological response variable for each of the analysis watersheds: linear, corresponding to no evidence of VSA processes $\left(Z_{i}=0\right)$, or nonlinear, corresponding to evidence of VSA processes $\left(Z_{i}=1\right)$.

Seasonal effects have been shown to influence nonlinearity in event-based rainfall-runoff ratios (Smith et al., 2005; Detty and McGuire, 2010; Meierdiercks et al., 2010b). During the growing season, evapotranspiration reduces soil moisture, allowing catchments to recover 
volume more quickly between events. We would therefore expect dormant season subsurface conditions to stay wetter longer and to be more associated with a constant response. In order to gain more clarity on potential sources of variation in nonlinear rainfall-runoff ratios, I specified an additional model to test whether growing season rainfall events have a statistically different rainfall-runoff relationship than dormant season events. The dormant season was defined as the months from October - March and the growing season was defined as the months from April September (Detty and McGuire, 2010).

The above-specified model [1] allowing for an additional effect of seasonality is shown in model [2]:

$$
\begin{aligned}
& \operatorname{runoff}_{i j}=\alpha_{1 i}+\beta_{1 i} \operatorname{rain}_{i j}+\beta_{2 i} \exp \left(\operatorname{rain}_{i j}\right)+ \\
& \alpha_{2 i} g_{i j}+\beta_{3 i} \operatorname{rain}_{i j} \times g_{i j}+\beta_{4 i} \exp \left(\operatorname{rain}_{i j}\right) \times g_{i j}+u_{i j}
\end{aligned}
$$

where $g_{i j}$ is a dummy variable equal to one if event $j$ occurred during the growing season and zero if event $j$ occurred during the dormant season. If the regression [2] for catchment $i$ results in significant coefficients $\alpha_{2 i}, \beta_{3 i}$, or $\beta_{4 i}$, this indicates that the rainfall-runoff ratio is statistically different during the growing season than during the dormant season. The model allowing for estimates effects for seasonality [2] was log-transformed in the same way the restricted model [1] was log-transformed. 
Predictors of Urban Variable Source Area

The choice of the exponential form of the term capturing nonlinearity is contrasted to the "breakpoint" or threshold conceptualization of nonlinearity that has been applied in other studies (e.g., Loperfido et al. (2014)). The exponentiated form is preferred for its ability to better reflect incremental exceedance of area-based storage within the catchment and thus, incremental hydrologic connectivity of areas to the downstream streamflow response. The choice to discretize the detection of VSA-type response is limited because it does not capture variation in the magnitude of nonlinearity; however, the focus of this analysis was on explaining the VSA process, rather than on predicting runoff magnitudes from rainfall depths.

\subsection{Logistic Regression of VSA on Catchment Characteristics}

After obtaining the binary VSA (nonlinear) or non-VSA (linear) response classification for each watershed was obtained, logistic regression was used to test which explanatory variables (catchment characteristics) contributed to the probability of a catchment exhibiting a nonlinear response. The probability of VSA-type response is expressed as an inverse logistic function of catchment characteristics in [3]:

$$
\operatorname{Pr}\left(Z_{i}=1\right)=\operatorname{logit}^{-1}\left(\boldsymbol{M}_{\boldsymbol{i}} \boldsymbol{\gamma}_{\boldsymbol{i}}\right)
$$

where $\boldsymbol{M}_{i}$ is the vector of $k$ characteristics for catchment $i\left(m_{1 i} \ldots m_{k i}\right)$, and $\boldsymbol{\gamma}_{\boldsymbol{i}}$ is the vector of coefficients for the characteristics of catchment $i$. Of particular interest was estimating the effect 
of development and specifically impervious surface on the probability of a catchment exhibiting a VSA-type (nonlinear) response. Other variables tested as part of the vector $\mathbf{M}$ included: average slope, average annual precipitation, number of data observations, size of the drainage area, percent of various land use types, stream order, basin compactness (a measure of elongation), and region. In the final models, theoretically important variables and variables statistically significant at the $\alpha=0.10,0.05$ and 0.01 levels were included.

To test my hypotheses, I fit [3] using two sets of models for each of the three datasets (national, BMA, and non-CSS only). The first set of models (Models 1A-1C, shown in Table 2) starts with percent undeveloped land as the sole predictor of VSA-type response (Model 1A), then sequentially adds geologic/morphologic controls as predictor variables in the model (Model 1B), followed by other development characteristic controls (Model 1C). The set of geologic/morphologic and meteorological controls in the models included average slope (\%), average annual precipitation $(\mathrm{cm} / \mathrm{yr})$, and catchment area $\left(\mathrm{km}^{2}\right)$. Watersheds with lower average slopes are expected to exhibit more variability in the saturated zone and from subsurface throughflow, which result in a VSA response (Dunne et al., 1975). Smaller basins are likely to exhibit flashier hydrological response, which may be associated with reduced VSA effects (Smith and Smith, 2015). The meteorological control included was the average total annual precipitation in the watershed. Higher annual precipitation is likely to be positively associated with humid climates that are likely more dominated by VSA processes than by Hortonian flow, all else being equal (Dunne et al., 1975; Miles and Band, 2015). Other development characteristic 
Predictors of Urban Variable Source Area

controls included percent TIA, percent developed open space, distance to combined sewer outfall and a binary variable for decentralized stormwater management practices. Percent undeveloped land was calculated from the GAGES II database by subtracting low, medium, and high density development and developed open space percentages from $100 \%$. Developed open space is a National Land Cover Dataset (NLCD) classification defined as the percent of the $30 \mathrm{~m} \times 30 \mathrm{~m}$ grids within the watershed that is estimated to have less than $20 \%$ impervious cover. Typically, these areas include large-lot single-family housing units, parks, golf courses and landscaped vegetation in developed areas.

In the second set of models, I removed percent undeveloped land as a predictor variable and only include development-type variables (Models 2A-2C, shown in Table 3). Starting with percent impervious area along with the geologic/morphologic and meteorological controls (Model 2A), I add in other development-type variables, for percent developed open space (Model 2B), and distance to combined sewer outfall, and decentralized stormwater management practices (Model 2C). Estimating the effects of development-type variables separately from the percent undeveloped area variable allows us to test how different development types contribute to explaining the variation in VSA-type response and avoid multicollinearity of explanatory variables.

Goodness-of-fit for the logistic regressions was assessed using two methods: McFadden's pseudo R-squared and a percent-correctly-predicted pseudo R-squared where the cutoff point was defined as the mean of the dependent variable (Wooldridge, 2010). The 
likelihood ratio test was used to evaluate whether the inclusion of additional explanatory variables led to statistical improvement of the model's fit to the data.

\section{RESULTS}

\subsection{Classification}

The robust catchment classification methodology resulted in 69 out of 91 total national-level catchments $(76 \%), 21$ of 34 total BMA catchments $(62 \%)$ and 44 out of 56 total non-CSS watersheds (78\%) being classified as having statistical evidence of VSA-processes. Among the national dataset basins, those classified as having nonlinear response had an average drainage area of $90.96 \mathrm{~km}^{2}$, while those classified as having a linear response had an average drainage area of $66.5 \mathrm{~km}^{2}$. T-test results showed that the difference in means was not statistically significant at the 0.05 level $\left(\mathrm{p}=.246, \mathrm{n}_{1}=69, \mathrm{n}_{2}=22\right)$. Table 1 shows the estimated linear and nonlinear coefficients and significance according to the robust standard errors for the BMA watersheds (national dataset results are included as supplemental information). Figure 5 illustrates the linear and nonlinear fits for several example watersheds. From these visual inspections of the fits to the data, I determined that the classifications based on the regression specifications and the robust standard error calculations for both the national (and non-CSS) dataset and the BMA dataset were satisfactory.

[TABLE 1: Estimated linear and nonlinear coefficients and robust standard errors for Baltimore Metropolitan Area watersheds] 
[FIGURE 5: Example plots of linear and nonlinear relationships between rainfall and runoff (log transformed). Gray areas represent $90 \%$ confidence interval of model fit with both linear and nonlinear terms included, using robust standard estimates. The solid line is the predicted relationship with both linear and nonlinear terms included. The dashed line is the predicted relationship with only the linear term included]

In order to determine whether the addition of the dummy variable for growing season and its interaction with the linear and nonlinear components of the regression significantly improved the fit of the model, I employed a heteroscedastic standard errors-robust F-test comparing the fits of the nested models [1] and [2]. In the majority of the catchments in both the national and BMA datasets, there was no significant improvement in model fit by including the dummy variable for growing season (57/91 catchments in the national dataset and 26/34 catchments in the BMA dataset exhibited no significant differences in fit compared to the restricted model [1], where the values of $\alpha_{2 i}, \beta_{3 i}$, and $\beta_{4 i}$ are all constrained to the value 0 ). Of the catchments that did exhibit improvement by incorporating seasonal differences, many estimated individual effects that were insignificant at the 0.05 level for all three additional seasonal terms (9/34 for the national dataset and 2/8 for the BMA dataset).

Among the seasonal models [2] that did exhibit some improvement over the restricted models [1], the interpretation of significantly estimated regression coefficients of may provide some additional insight into the dynamics of urban VSA runoff behavior. Figure 6 shows the classifications of each basin included in this study, first by whether the fit of the model was 
improved with the inclusion season-specific variables, then by the year-round classification as exhibiting evidence of VSA-behavior, and lastly, by significance and signs of estimated seasonspecific effects. Figure 6 shows that among those catchments for which the addition of the seasonal variables significantly improved fit, $9 / 20$ of the national dataset and 2/8 of the BMA dataset had insignificant effects for all three variables. For both datasets however, the next frequent classification among those with improved models was for non-VSA basins with significant nonlinear behavior during the growing season. This coefficient was estimated as positive in 4/5 national catchments in this category and 2/2 of BMA catchments in this category. Both these findings are in agreement with the present understanding of VSA runoff generation, which suggests that variable source area dynamics would be more pronounced during the growing season, when evapotranspiration allows basins to recover storage volume more quickly (Detty and McGuire, 2010).

[FIGURE 6 Classification of all analysis basins included in this study based on model improvement with inclusion of seasonal controls, significance of nonlinear term (evidence of VSA behavior), and significance and sign of estimated coefficients associated with effect of rainfall-runoff ratio relationship during the growing season (April - Sep). Of catchments whose models were improved by controlling for seasonality and had significant individual coefficients, the highest frequency that appeared were for VSA catchments with positive coefficients for the 
Predictors of Urban Variable Source Area

nonlinear seasonal term. This is in agreement with previous theory and findings that VSA response should be more pronounced during the growing season.]

\subsection{Predictors of Urban VSA}

Table 2 shows the results of the regressions that include the percent of the watershed that is undeveloped as a predictor of the VSA-classification. For the national dataset, percent undeveloped area alone was a significant predictor of a VSA-type response. A $1 \%$ increase in the percent undeveloped land within a watershed was associated with a $3.5 \%$ increase in the odds of a watershed exhibiting VSA-type response. For all three datasets, including morphological and meteorological controls in Model 1B led to significant improvement over Model 1A. A likelihood ratio test between Models 1B and 1A yielded p-values of 0.035, 0.00087, and 0.0084 for the national dataset, BMA dataset and CSS dataset, respectively. Based on Model $1 \mathrm{~B}$, the effect of a $1 \%$ increase in undeveloped land was associated with between $5.5 \%$ and $10.8 \%$ increase in the odds of the watershed exhibiting evidence of a VSA-type response, controlling for slope, precipitation, and catchment area.

[TABLE 2: Results of logistic regression of percent undeveloped land and other controls on probability of VSA-type response]

Adding in controls for development types sequentially did not further statistically improve the model fits for the national or BMA datasets but some improvement was shown with the non-CSS dataset. One model (not shown in Table 2) estimated with the non-CSS 
dataset which included percent developed open space, percent undeveloped land and the morphological and meteorological controls (but excluding percent impervious area), did estimate statistically significant results for both undeveloped land and developed open space and this model was shown to be a statistical improvement over Model 1B ( $\mathrm{p}=0.03053)$. The effect of undeveloped land was similar to that estimated in Model 1B (9.32\%), but the effect of developed open space was estimated to be $-8.232 \%(p=0.0463)$. In contrast, the effect of impervious area is not significant at the $\alpha=0.05$ level when included with undeveloped area with any of the datasets. This suggests that developed open space functions more similarly to what we would expect from impervious area, and that this effect is most prevalent watersheds that do not have CSS.

Model 1C, which also includes percent impervious area as an explanatory variable, showed slightly significant $(\mathrm{p}=0.09)$ improvement over Model 1B for the non-CSS dataset, but none of the development variable coefficients were estimated to be statistically significant from zero. Model 1C exhibited the problem of rather high variance inflation factors for multiple variables for all three datasets. High VIFs are an indication of multicollinearity between the explanatory variables. Generally, VIF values $>10$ result in unreliable estimates (Kutner et al., 2004). When percent TIA was removed from Model 1C for the non-CSS dataset, all VIFs fell below 2, suggesting that the source of collinearity was between percent undeveloped and TIA and percent developed open space and TIA, and not between percent developed open space and percent undeveloped. 
A second set of models excluded the percent undeveloped variable to avoid multicollinearity and focus on the effects of percent impervious area, which is commonly identified as the strongest factor in decreased catchment storage and flashier hydrologic response (Table 3). The effect of impervious surface area was not found to be a significant predictor of a VSA-type response until other contextual factors were controlled for. Adding morphologic and meteorological controls (Model 2A), a significant effect was only estimated with the BMA dataset. A $1 \%$ increase in the percent impervious area was associated with an $11.1 \%$ decrease in the odds of a VSA-type response. TIA only became statistically significant for all three dataset after also controlling for percent developed open space (Model 2B) and a likelihood ratio test also indicates that the model improvement over $2 \mathrm{~A}$ is statistically significant ( $\mathrm{p}$-values for the improvement of Model 2B over Model 2A were 0.01276, 0.08941, and 0.001745 for the national, BMA, and non-CSS datasets, respectively). These models estimated between an $8.0 \%$ and $17.9 \%$ decrease in the odds of VSA-type response associated with a $1 \%$ increase in TIA.

[TABLE 3: Results of logistic regression of development types and other controls on probability of VSA-type response] 
The effect of developed open space was nearly equal in magnitude to that of TIA. A $1 \%$ increase in developed open space was associated with between $8.6 \%$ and $15.2 \%$ decrease in the odds of a VSA-type response. Adding additional variables representing type of development, such as distance to combined sewer outfall and presence of a retention, detention or infiltrationbased stormwater management program (Model 2C), neither significantly improved model fit nor resulted in additional significant estimated effects (likelihood ratio test $\mathrm{p}$ values for improvement of Model 2C over 2B were 0.553 and 0.308 for the national and BMA datasets, respectively). Model 2C for the national dataset had acceptable VIF values, and controlling for the distance to the nearest combined sewer outfall and presence of distributed stormwater infrastructure resulted in little change to the estimated effects of TIA and developed open space, demonstrating stability of the model. The two models that showed statistically significant improvements-Models $1 \mathrm{~B}$ and $2 \mathrm{~B}-$ had similar goodness-of-fit measures and estimated effects of significant controls, further increasing confidence that the results were not spurious.

\section{DISCUSSION}

\subsection{Effect of undevleoped Land compared to land development variables in explaining VSA response}

The results from models that included undeveloped land as an independent variable show that in general, development type variables add little compared to the explanatory power of undeveloped land for predicting VSA response. This is especially true when morphologic 
Predictors of Urban Variable Source Area

and meteorological controls are included. When no additional controls are included in the regressions, the effect of undeveloped land is marginally significant, while that of TIA is not significantOnly when controls for watershed morphologic and meteorological conditions does TIA become a stable predictor of VSA-response. This result is important considering the attention that impervious area as a singular metric has been given over the years, especially for land use planning purposes. The conditional significance of impervious area highlights the need to incorporate contextualizing factors into the understanding of catchment-scale hydrological response.

\subsection{Effect of open space in urban areas on VSA response}

As expected, the effect of TIA on VSA-response is negative: a 1\% increase in TIA within the watershed is associated with between $8.0 \%$ and $17.9 \%$ decrease in the odds of detection of a VSA-type response, controlling for other factors. Less expected is that developed open area (low density development) also has a negative effect on VSA-type response almost equal in magnitude to TIA. This suggests that on average, developed pervious area is also associated with Hortonian-flow dominated responses compared to undeveloped areas, a result that has also been confirmed by others (Smith et al., 2015). For land use planners, this means it is not enough to limit imperviousness of new development. In order to preserve VSA-type response, it is necessary to limit even low-density development. TIA is highly correlated with overall development levels (Pearson's rho $=0.78,0.80$, and 0.91 for the national, BMA and non-CSS datasets, respectively), which explains why this particular metric may have been useful for land 
use planners in the past. Developed open space, which was shown in this study to add significantly to the explanatory power of TIA, is not correlated with overall development (Pearson's rho $=-0.13,-0.09,0.15$ for the national, BMA and non-CSS datasets, respectively). This weak correlation, along with the relative invisibility of runoff generation on pervious surfaces compared to impervious surfaces, may explain why the effect of developed open space has been overlooked.

There are several possible explanations for why developed open space has a negative effect on VSA-type response. Developed open space in the NLCD is defined as development that is less than $20 \%$ impervious, so these areas could still contain roads and drainage infrastructure that increase hydraulic connectivity. Urban pervious surfaces could have very little storage due to compaction and localized subsurface saturation due to lawn watering and leakage and therefore lead to saturation overflow conditions even during very small events (Lerner, 2002; Bhaskar and Welty, 2012; Smith and Smith, 2015). Although this process is physically more similar to Dunne's VSA concept of saturation overland flow, if storage is minimal, the hydrological response at this level of analysis is indistinguishable from Hortonian overland flow.

\subsection{Effects of stormwater management infrastructure on VSA response}

In the national dataset, no coefficients estimated for stormwater management control variables had statistically significant effects, and distance to CSO in the BMA dataset had only a 
marginally significant negative effect on VSA response. Many urban areas in the Northeast and Midwest US are served by combined sewer systems that collect wastewater and stormwater runoff within the same system. During small rain events, these collection systems do not discharge directly to streams, but direct all flows to the wastewater treatment plant, after which, runoff generated in one catchment may be discharged in another. The presence of this kind of infrastructure might suppress the detection of runoff response in highly urbanized areas, mitigating some of the negative effect of high levels of impervious surface in urbanized areas and resulting in decreased (less negative) effects on the probability of VSA compared to suburban areas. The more negative effect of developed open space estimated from the non-CSS dataset offers some supporting evidence that this is true: among watersheds in which runoff is not intercepted by wastewater collection and treatment systems, there is more of a Hortoniantype hydrological response. The data used in this analysis and the formulation of urban VSA include both runoff generation processes and the effects of intermediary structures that could confound the detection of a non-constant rainfall-runoff relationship (Figure 1). However, previously demonstrated empirical evidence that variable source dynamics are more pronounced during summer months were also supported. It should be noted however, that the implications of a "VSA" type response that results from runoff being sent to a wastewater treatment plant during small storms but discharging runoff during large events has very different implications for watershed management than more natural VSA runoff production processes. Estimating the effect of retention, detention and infiltration-based stormwater 
management practices from the presence of guidelines including these practices does not necessarily reflect extent of implementation. However, previous research has shown that despite being constructed with modern detention and retention ponds, developed basins in Maryland still functioned more similarly to basins without such infrastructure than to an undeveloped, forested basin (Meierdiercks et al., 2010b).

There are limitations of the data used in this analysis. While the GAGES II dataset is valuable because it allows for a cross-sectional analysis of many watersheds across the US, the resolution of land cover and precipitation data is too low to distinguish among specific physical processes of localized runoff generation. The particular processes and pathways within urbanized catchments ideally should be assessed in the field, and therefore, the conclusions of this study should be understood as the 'average' effects of the covariates included in the regressions, as measured at the stream gauge. It could be that issues of resolution among the urbanized catchments studied may mask the specific connectivity conditions of 'developed open space.'

\section{CONCLUSIONS}

This study confirms the need to move away from impervious surface as a singular metric for hydrological response, but has particular implications for land use planners and watershed managers. Previous emphasis on limiting imperviousness of new development suggests that low density, suburban development results in less disruption of hydrological 
Predictors of Urban Variable Source Area

response because of the presence of open space to mitigate flows. This study provides evidence that developed open space functions more similarly to impervious area than it does to natural areas, and shows that there is no evidence that developed open space promotes VSA dynamics. This finding may provide watershed managers and land use planners with additional rationale to promote higher density urban development or redevelopment and preserve naturalized areas rather than develop at low densities with more developed open space. It also implies that bulk lot coverage or zoning regulations that limit imperviousness but do not specifically address preservation of naturalized vegetation or native, undisturbed soils should be reexamined.

\section{ACKNOWLEDGEMENTS}

I would like to thank Claire Welty, Brian Miles, Jim Smith, Brianne Smith, Mary L Baeck, Chris Nytch and three anonymous reviewers for their input and advice on earlier drafts of this research. 


\section{REFERENCES}

Alberti M, Booth DB. 2007. The impact of urban patterns on aquatic ecosystems: An empirical analysis in Puget lowland sub-basins. Landscape and Urban Planning (4): 345-361 DOI: 10.1016/j.landurbplan.2006.08.001

Alley W, Veenhuis J. 1983. Effective Impervious Area in Urban Runoff Modeling. Journal of Hydraulic Engineering 109 (2): 313-319 DOI: 10.1061/(ASCE)0733-9429(1983)109:2(313)

Arnold CL, Gibbons CJ. 1996. Impervious Surface Coverage: The Emergence of a Key Environmental Indicator. Journal of the American Planning Association 62 (2): 243-258 DOI: $10.1080 / 01944369608975688$

Bhaskar A, Welty C, Maxwell RM, Miller AJ. 2015. Untangling the effects of urban development on subsurface storage in Baltimore. Water Resources Research 51 (2): 1158-1181 DOI: 10.1002/2014WR016039

Bhaskar AS, Welty C. 2012. Water Balances along an Urban-to-Rural Gradient of Metropolitan Baltimore, 2001-2009. Environmental \& Engineering Geoscience 18 (1): 37-50 DOI: 10.2113/gseegeosci.18.1.37

Booth DB, Jackson CR. 1997. Urbanization of Aquatic Systems: Degradation Thresholds, Stormwater Detection, and the Limits of Mitigation1. JAWRA Journal of the American Water Resources Association 33 (5): 1077-1090 DOI: 10.1111/j.1752-1688.1997.tb04126.x 
Predictors of Urban Variable Source Area

Boyd MJ, Bufill MC, Knee RM. 1993. Pervious and impervious runoff in urban catchments. Hydrological Sciences Journal 38 (6): 463-478 DOI: 10.1080/02626669309492699

Boyd MJ, Bufill MC, Knee RM. 1994. Predicting pervious and impervious storm runoff from urban drainage basins. Hydrological Sciences Journal 39 (4): 321-332 DOI: $10.1080 / 02626669409492753$

Brabec E. 2002. Impervious Surfaces and Water Quality: A Review of Current Literature and Its Implications for Watershed Planning. Journal of Planning Literature 16 (4): 499-514

Brandes D, Cavallo GJ, Nilson ML. 2005. Base Flow Trends in Urbanizing Watersheds of the Delaware River Basin. JAWRA Journal of the American Water Resources Association 41 (6): 1377-1391 DOI: 10.1111/j.1752-1688.2005.tb03806.x

Detty JM, McGuire KJ. 2010. Topographic controls on shallow groundwater dynamics: implications of hydrologic connectivity between hillslopes and riparian zones in a till mantled catchment. Hydrological Processes 24 (16): 2222-2236 DOI: 10.1002/hyp.7656

Dinicola RS. 1990. Characterization and Simulation of Rainfall-Runoff Relations for Headwater Basins in Western King and Snohomish Counties, Washington State. 89-4052. USGS, Tacoma, Washington.

Doyle WH, Miller JE. 1980. Calibration of a Distributed Routing Rainfall-Runoff Model at Four Urban Sites near Miami, Florida. USGS. Available at: http://pubs.usgs.gov/wri/1980/0001/report.pdf 
Predictors of Urban Variable Source Area

Dunne T. 1978. Field studies of hillslope flow processes. In Hillslope Hydrology, Kirkby MJ (ed.).John Wiley; 227-293.

Dunne T, Black RD. 1970. Partial Area Contributions to Storm Runoff in a Small New England Watershed. Water Resources Research 6 (5): 1296-1311 DOI: 10.1029/WR006i005p01296

Dunne T, Moore TR, Taylor CH. 1975. Recognition and Prediction of Runoff-Producing Zones in Humid Regions. Hydrological Sciences - Bulletin (3)

Easton ZM, Gérard-Marchant P, Walter MT, Petrovic AM, Steenhuis TS. 2007. Hydrologic assessment of an urban variable source watershed in the northeast United States. Water Resources Research 43 (3): W03413 DOI: 10.1029/2006WR005076

Ebrahimian A, Wilson BN, Gulliver JS. 2016. Improved methods to estimate the effective impervious area in urban catchments using rainfall-runoff data. Journal of Hydrology 536: 109-118 DOI: 10.1016/j.jhydrol.2016.02.023

Falcone JA, Carlisle DM, Wolock DM, Meador MR. 2010. GAGES: A stream gage database for evaluating natural and altered flow conditions in the conterminous United States. Ecology 91 (2): 621-621 DOI: 10.1890/09-0889.1

Fuka D, Walter M, Archibald J, Steenhuis T, Easton Z. 2014. EcoHydRology: A community modeling foundation for Eco-Hydrology. $R$ package version 0.4.12. Available at: http://CRAN.R-project.org/package=EcoHydRology

Gobel P, Stubbe H, Weinert M, Zimmermann J, Fach S, Dierkes C, Kories H, Messer J, Mertsch V, Geiger WF, et al. 2004. Near-natural stormwater management and its effects on the 
Predictors of Urban Variable Source Area $\quad$ LIM water budget and groundwater surface in urban areas taking account of the hydrogeological conditions. Journal of Hydrology 299 (3-4): 267-283 DOI: 10.1016/j.jhydrol.2004.08.013

Goldshleger N, Karnibad L, Shoshany M, Asaf L. 2012. Generalising urban runoff and street network density relationship: A hydrological and remote-sensing case study in Israel. Urban Water Journal 9 (3): 189-197 DOI: 10.1080/1573062X.2011.652128

Hamel P, Daly E, Fletcher TD. 2013. Source-control stormwater management for mitigating the impacts of urbanisation on baseflow: A review. Journal of Hydrology 485: 201-211 DOI: 10.1016/j.jhydrol.2013.01.001

Hammer TR. 1972. Stream channel enlargement due to urbanization. Water Resources Research 8 (6): 1530-1540 DOI: 10.1029/WR008i006p01530

Harbor JM. 1994. A Practical Method for Estimating the Impact of Land-Use Change on Surface Runoff, Groundwater Recharge and Wetland Hydrology. Journal of the American Planning Association 60 (1): 95-108 DOI: 10.1080/01944369408975555

Hatt BE, Fletcher TD, Walsh CJ, Taylor SL. 2004. The Influence of Urban Density and Drainage Infrastructure on the Concentrations and Loads of Pollutants in Small Streams. Environmental Management 34 (1): 112-124 DOI: 10.1007/s00267-004-0221-8

Hewlett JD, Hibbert AR. 1967. Factors affecting the response of small watersheds to precipitation in humid areas. In Forest Hydrology, Sopper WE, , Lull HW (eds).275-290. 
Predictors of Urban Variable Source Area

LIM

James AL, Roulet NT. 2007. Investigating hydrologic connectivity and its association with threshold change in runoff response in a temperate forested watershed. Hydrological Processes 21 (25): 3391-3408 DOI: 10.1002/hyp.6554

Jencso KG, McGlynn BL, Gooseff MN, Wondzell SM, Bencala KE, Marshall LA. 2009. Hydrologic connectivity between landscapes and streams: Transferring reach- and plotscale understanding to the catchment scale: CONNECTIVITY BETWEEN LANDSCAPES AND STREAMS. Water Resources Research 45 (4): n/a-n/a DOI: 10.1029/2008WR007225

Knighton J, White E, Lennon E, Rajan R. 2013. Development of probability distributions for urban hydrologic model parameters and a Monte Carlo analysis of model sensitivity. Hydrological Processes: n/a-n/a DOI: 10.1002/hyp.10009

Kutner M, Nachtsheim C, Neter J. 2004. Applied Linear Regression Models-4th Edition with Student CD. McGraw-Hill Education: Boston; New York.

Lee J, Heaney J. 2003. Estimation of Urban Imperviousness and its Impacts on Storm Water Systems. Journal of Water Resources Planning and Management 129 (5): 419-426 DOI: 10.1061/(ASCE)0733-9496(2003)129:5(419)

Leopold L. 1968. Hydrology for urban land planning - a guidebook on the hydrologic effects of urban land use. 554. United States Department of the Interior.

Lerner DN. 2002. Identifying and quantifying urban recharge: a review. Hydrogeology Journal 10 (1): 143-152 DOI: 10.1007/s10040-001-0177-1 
Predictors of Urban Variable Source Area

Lins HF. 2012. USGS Hydro-Climatic Data Network 2009 (HCDN-2009). Fact Sheet 2012-3047. USGS, Reston, VA.

Loperfido JV, Noe GB, Jarnagin ST, Hogan DM. 2014. Effects of distributed and centralized stormwater best management practices and land cover on urban stream hydrology at the catchment scale. Journal of Hydrology 519: 2584-2595 DOI: 10.1016/j.jhydrol.2014.07.007

McBride M, Booth DB. 2005. Urban Impacts on Physical Stream Condition: Effects of Spatial Scale, Connectivity, and Longitudinal Trends1. JAWRA Journal of the American Water Resources Association 41 (3): 565-580 DOI: 10.1111/j.1752-1688.2005.tb03755.x

McDonnell JJ. 2003. Where does water go when it rains? Moving beyond the variable source area concept of rainfall-runoff response. Hydrological Processes 17 (9): 1869-1875 DOI: 10.1002/hyp.5132

McGlynn BL, McDonnell JJ. 2003. Quantifying the relative contributions of riparian and hillslope zones to catchment runoff. Water Resources Research 39 (11): 1310 DOI: 10.1029/2003WR002091

McGlynn BL, McDonnell JJ, Seibert J, Kendall C. 2004. Scale effects on headwater catchment runoff timing, flow sources, and groundwater-streamflow relations. Water Resources Research 40 (7): W07504 DOI: 10.1029/2003WR002494

Meierdiercks KL, Smith JA, Baeck ML, Miller AJ. 2010a. Analyses of Urban Drainage Network Structure and its Impact on Hydrologic Response1: Analyses of Urban Drainage 
Predictors of Urban Variable Source Area

Network Structure and Its Impact on Hydrologic Response. JAWRA Journal of the American Water Resources Association 46 (5): 932-943 DOI: 10.1111/j.17521688.2010.00465.x

Meierdiercks KL, Smith JA, Baeck ML, Miller AJ. 2010b. Heterogeneity of Hydrologic Response in Urban Watersheds1. JAWRA Journal of the American Water Resources Association 46 (6): 1221-1237 DOI: 10.1111/j.1752-1688.2010.00487.x

Mejía AI, Moglen GE. 2010. Impact of the spatial distribution of imperviousness on the hydrologic response of an urbanizing basin. Hydrological Processes 24 (23): 3359-3373 DOI: 10.1002/hyp.7755

Miles B, Band LE. 2015. Green infrastructure stormwater management at the watershed scale: urban variable source area and watershed capacitance. Hydrological Processes 29 (9): 2268-2274 DOI: 10.1002/hyp.10448

Miles BC. 2014. Small-scale residential stormwater management in urbanized watersheds: A geoinformatics-driven ecohydrology modeling approach.Ph.D., The University of North Carolina at Chapel Hill, United States -- North Carolina. Available at: http://search.proquest.com/docview/1648168622/abstract? [Accessed 9 September 2015]

Moglen GE, Kim S. 2007. Limiting Imperviousness. Journal of the American Planning Association 73 (2): 161-171 DOI: 10.1080/01944360708976150

Newall P, Walsh CJ. 2005. Response of epilithic diatom assemblages to urbanization influences. Hydrobiologia 532 (1-3): 53-67 DOI: 10.1007/s10750-004-9014-6 
Predictors of Urban Variable Source Area

Ocampo CJ, Sivapalan M, Oldham C. 2006. Hydrological connectivity of upland-riparian zones in agricultural catchments: Implications for runoff generation and nitrate transport. Journal of Hydrology 331 (3-4): 643-658 DOI: 10.1016/j.jhydrol.2006.06.010

Ogden FL, Raj Pradhan N, Downer CW, Zahner JA. 2011. Relative importance of impervious area, drainage density, width function, and subsurface storm drainage on flood runoff from an urbanized catchment. Water Resources Research 47 (12): W12503 DOI: 10.1029/2011WR010550

Palla A, Gnecco I. 2015. Hydrologic modeling of Low Impact Development systems at the urban catchment scale. Journal of Hydrology 528: 361-368 DOI: 10.1016/j.jhydrol.2015.06.050

Penna D, Tromp-van Meerveld HJ, Gobbi A, Borga M, Dalla Fontana G. 2011. The influence of soil moisture on threshold runoff generation processes in an alpine headwater catchment. Hydrol. Earth Syst. Sci. 15 (3): 689-702 DOI: 10.5194/hess-15-689-2011

Shepherd JM. 2005. A Review of Current Investigations of Urban-Induced Rainfall and Recommendations for the Future. Earth Interactions 9 (12): 1-27 DOI: 10.1175/EI156.1

Shuster WD, Bonta J, Thurston H, Warnemuende E, Smith DR. 2005. Impacts of impervious surface on watershed hydrology: A review. Urban Water Journal 2 (4): 263-275 DOI: $10.1080 / 15730620500386529$

Smith BK, Smith JA. 2015. The Flashiest Watersheds in the Contiguous United States. Journal of Hydrometeorology 16 (6): 2365-2381 DOI: 10.1175/JHM-D-14-0217.1 
Predictors of Urban Variable Source Area

Smith BK, Smith JA, Baeck ML, Miller AJ. 2015. Exploring storage and runoff generation processes for urban flooding through a physically based watershed model. Water Resources Research 51 (3): 1552-1569 DOI: 10.1002/2014WR016085

Smith JA, Baeck ML, Meierdiercks KL, Nelson PA, Miller AJ, Holland EJ. 2005. Field studies of the storm event hydrologic response in an urbanizing watershed. Water Resources Research 41 (10): W10413 DOI: 10.1029/2004WR003712

Smith JA, Baeck ML, Villarini G, Welty C, Miller AJ, Krajewski WF. 2012. Analyses of a longterm, high-resolution radar rainfall data set for the Baltimore metropolitan region. Water Resources Research 48 (4): W04504 DOI: 10.1029/2011WR010641

Tague C, Pohl-Costello M. 2008. The Potential Utility of Physically Based Hydrologic Modeling in Ungauged Urban Streams. Annals of the Association of American Geographers 98 (4): 818833 DOI: 10.1080/00045600802099055

Tromp-van Meerveld HJ, McDonnell JJ. 2006. Threshold relations in subsurface stormflow: 1. A 147-storm analysis of the Panola hillslope. Water Resources Research 42 (2): W02410 DOI: 10.1029/2004WR003778

TVA. 1965. Area-stream factor correlation, a pilot study in the Elk River basin. BulletinInternational Association of Scientific Hydrology 10 (2): 22-37

US EPA O of W. 2004. Report to Congress: Impacts and Control of CSOs and SSOs. EPA 833-R04-001. EPA. 
Predictors of Urban Variable Source Area

USFS. 1961. Some ideas about storm runoff and baseflow. Annual Report. US Forest Service, South-eastern Forest Experiment Station.

Wenninger J, Uhlenbrook S, Lorentz S, Leibundgut C. 2008. Identification of runoff generation processes using combined hydrometric, tracer and geophysical methods in a headwater catchment in South Africa / Identification des processus de formation du débit en combinat la méthodes hydrométrique, traceur et géophysiques dans un bassin versant sud-africain. Hydrological Sciences Journal 53 (1): 65-80 DOI: 10.1623/hysj.53.1.65

Wigmosta MS, Burges SJ. 1997. An adaptive modeling and monitoring approach to describe the hydrologic behavior of small catchments. Journal of Hydrology 202 (1-4): 48-77 DOI: 10.1016/S0022-1694(97)00057-7

Wooldridge JM. 2010. Econometric Analysis of Cross Section and Panel Data. The MIT Press: Cambridge, Mass.

Zeileis A. 2004. Econometric Computing with HC and HAC Covariance Matrix Estimators. Journal of Statistical Software 11 (10): 1-17 
(a)

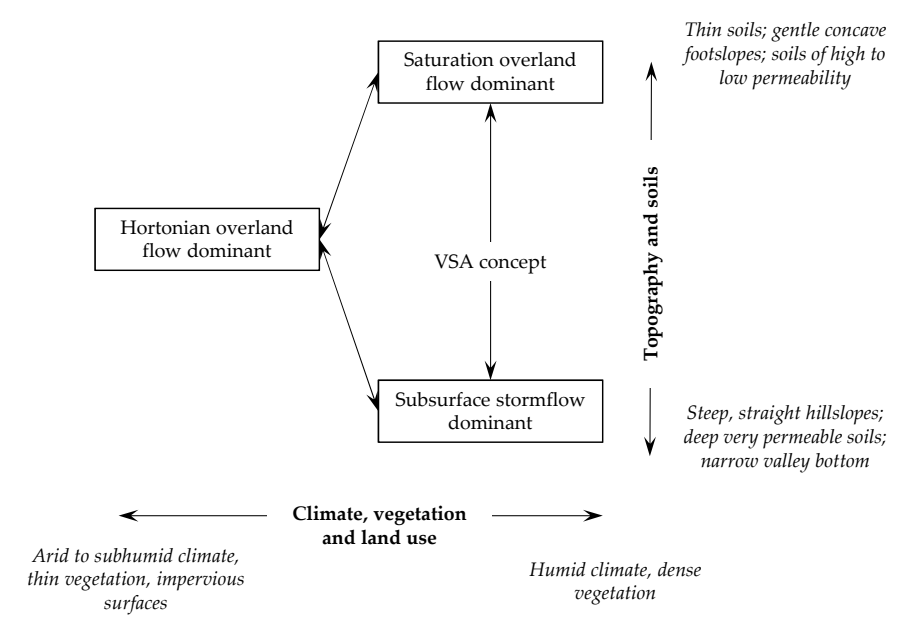

(c)

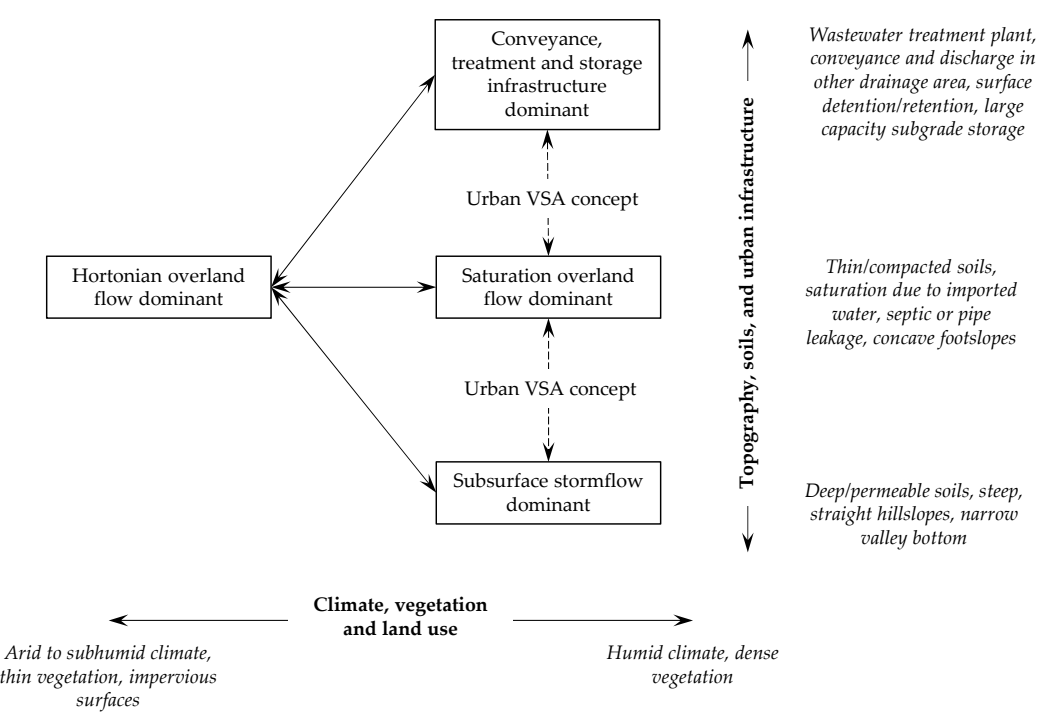

(b)

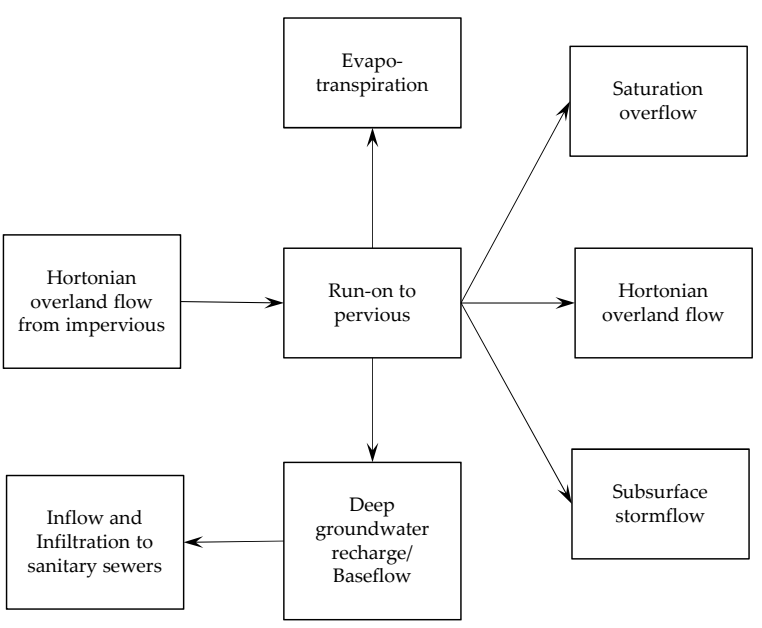
medium density urbanized watersheds. (c) Conceptualization of runoff generation process in low to high density urbanized watershed and potential causes of observed variable source area, including infrastructure storage and leakage. (a) and (b) reproduced from Miles and Band (2015), used with permission from Wiley

http://mc.manuscriptcentral.com/hyp 
Figure 2. Locations of national dataset and non-CSS dataset analysis catchments $279 \times 215 \mathrm{~mm}(300 \times 300 \mathrm{DPI})$ 


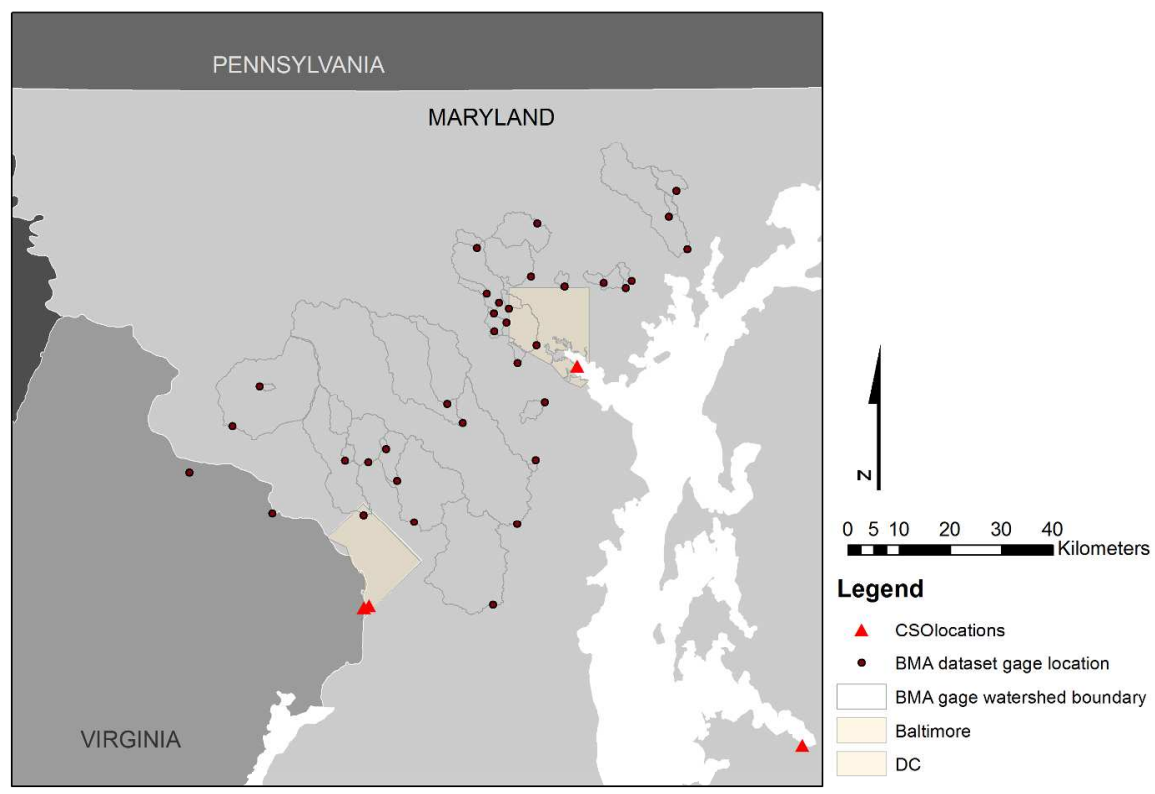

Figure 3. BMA dataset gage locations and basin boundaries $279 \times 215 \mathrm{~mm}(300 \times 300 \mathrm{DPI})$ 


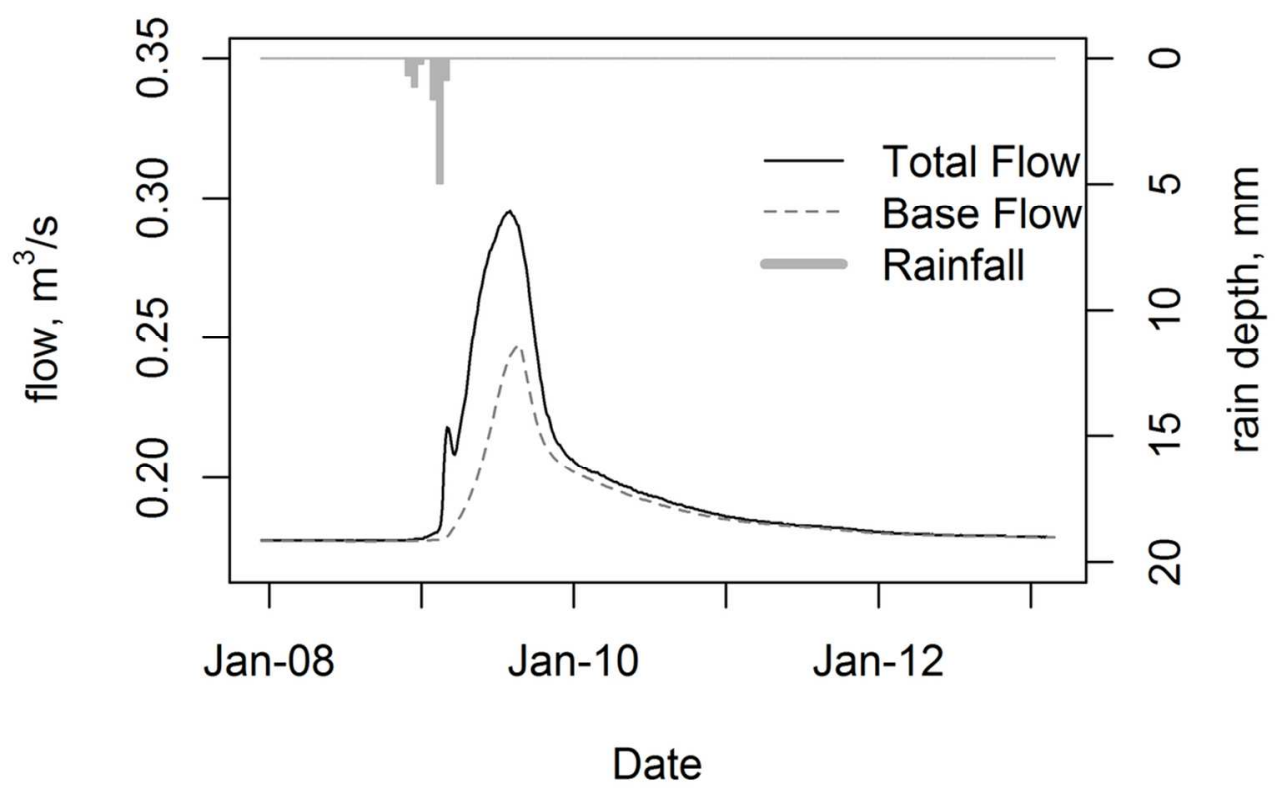

Figure 4. Example of hydrograph separation using R package 'EcoHydRology' for the watershed in our sample with the largest drainage area, Salado Creek in San Antonio, TX (drainage area $=505.8 \mathrm{~km} 2$ ). The flow response to a $38.1 \mathrm{~mm}$ ( 1.5 inch) total rainfall depth is shown. The response returns to baseflow conditions within the 36 hour period. $101 \times 81 \mathrm{~mm}(300 \times 300 \mathrm{DPI})$ 
Non-Variable
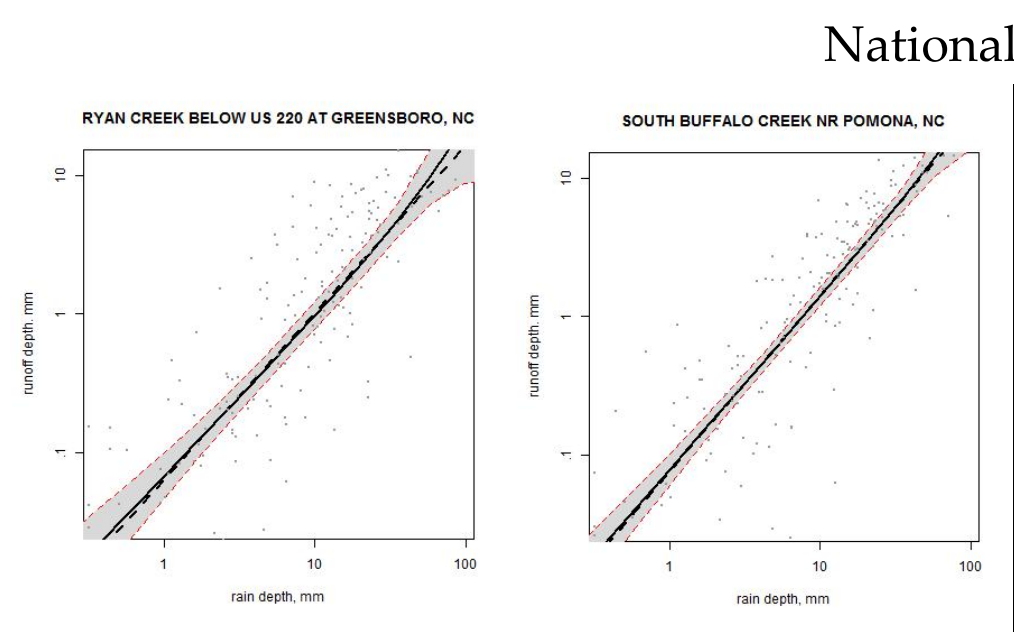

Variable
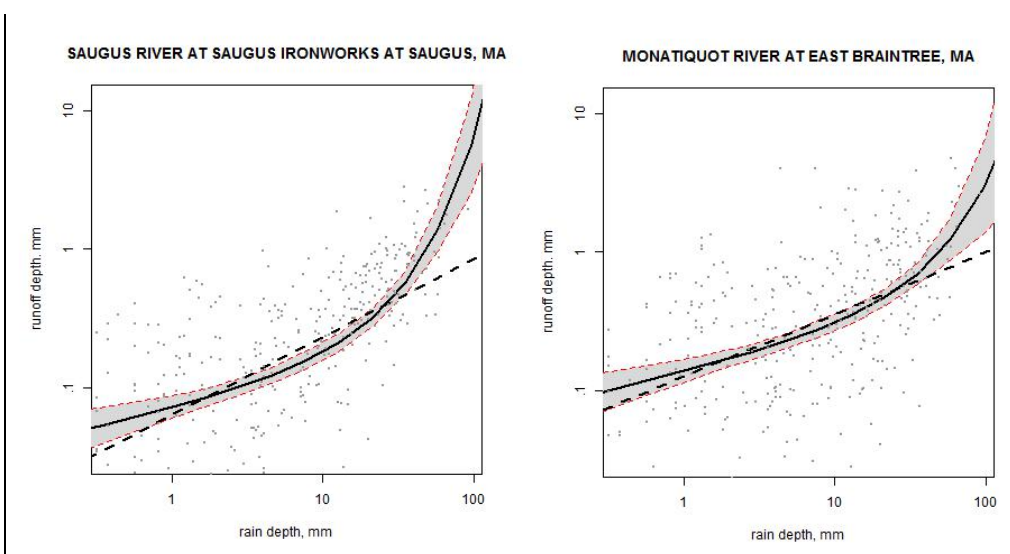

BMA dataset
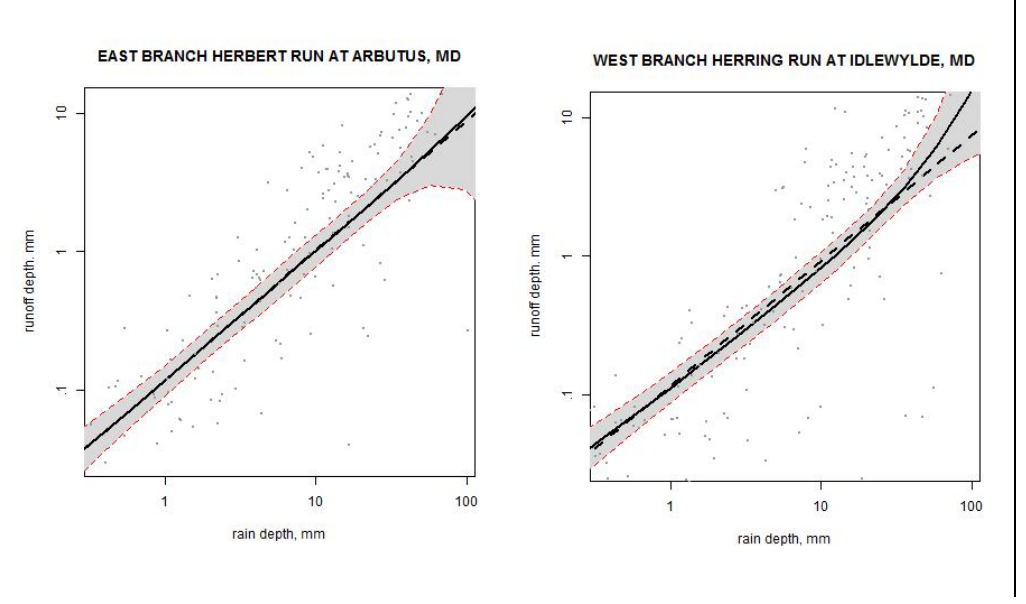

PAINT BRANCH TRIBUTARY NEAR COLESVILLE, MD
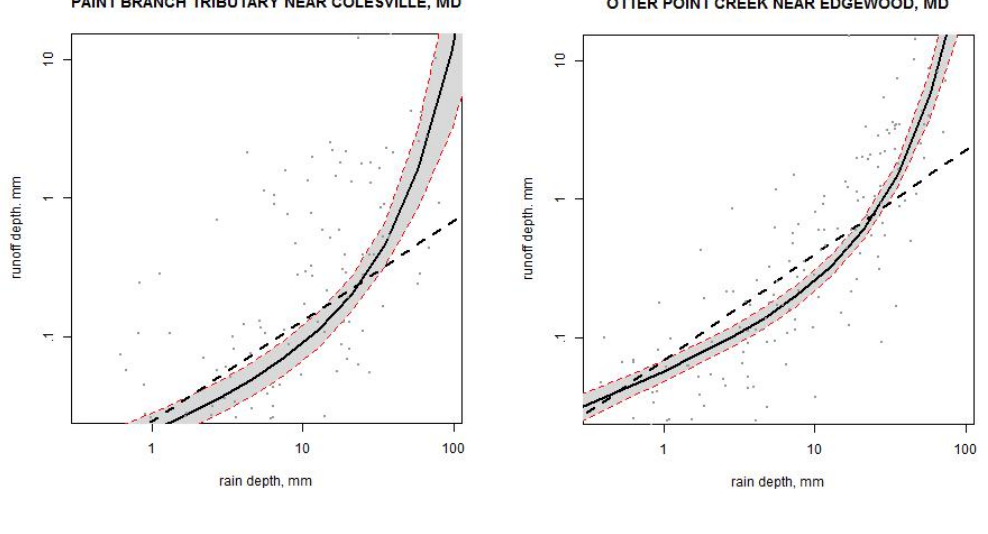

FIGURE 5: Example plots of linear and nonlinear relationships between rainfall and runoff (log transformed). Gray areas represent $90 \%$ confidence interval of model fit with both linear and nonlinear terms included, using robust standard estimates. The solid line is the predicted relationship with both linear and nonlinear terms included. The dashed line is the predicted relationship with only the linear term included 

Seasonal Model Improved?
(heteroscedastic-
robust $f$-test $p<0.05$ )
Nonlinear term significant?

\section{Growing season nonlinear term significant?} $\left(\beta_{4} p<0.05\right)$
Growing season linear term significant? $\left(\beta_{3} p<0.05\right)$

Growing season intercept term significant? $\left(\alpha_{2} p<0.05\right)$

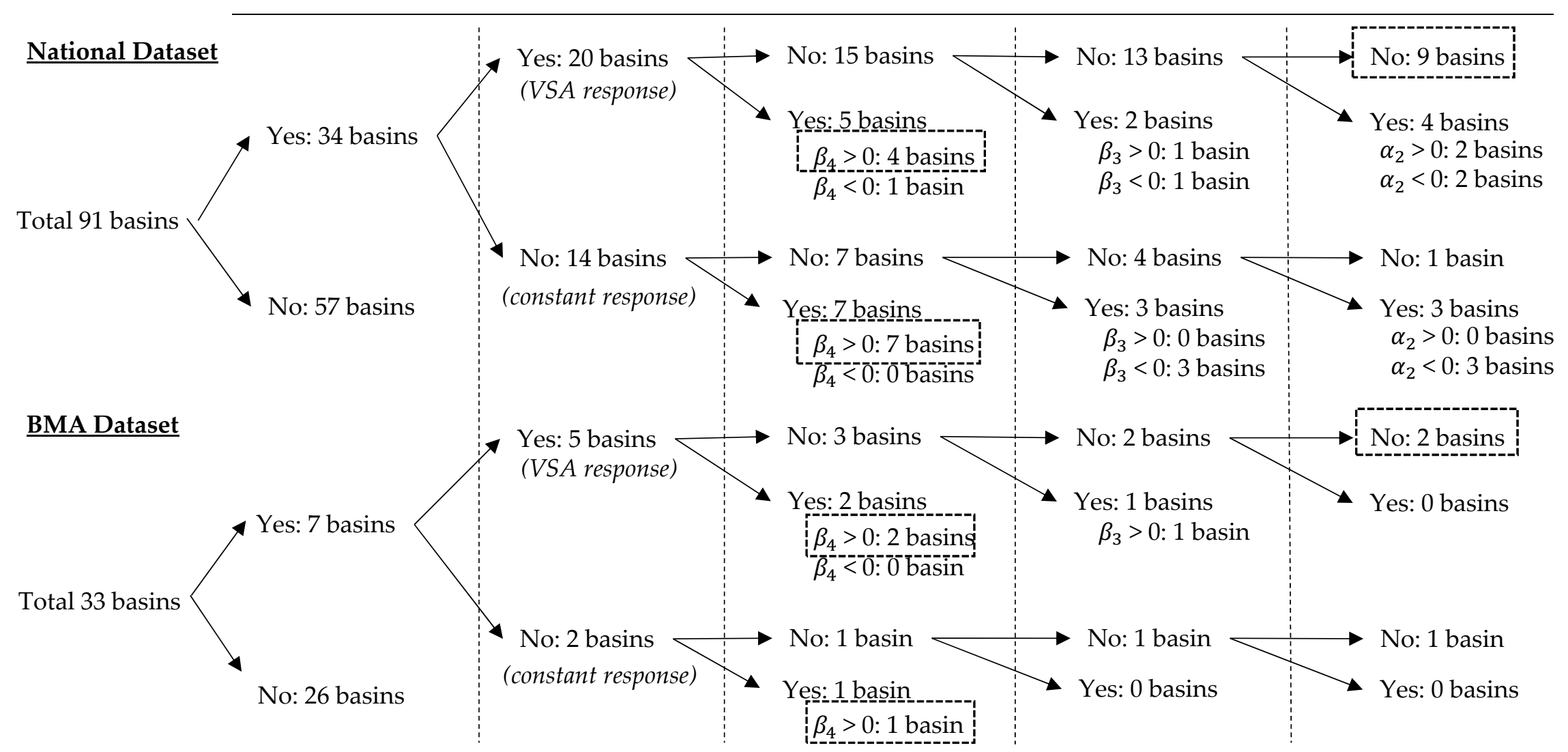

FIGURE 6 Classification of all analysis basins included in this study based on model improvement with inclusion of seasonal controls, significance of nonlinear term (evidence of VSA behavior), and significance and sign of estimated coefficients associated with effect of rainfall-runoff ratio relationship during the growing season (April - September). Of catchments whose models were improved by controlling for seasonality and had significant individual coefficients, the highest frequency that appeared were for VSA catchments with positive coefficients for the nonlinear seasonal term. This is in agreement with previous theory and findings that VSA response should be more pronounced during the growing season. 
Table 1. Estimated linear and nonlinear coefficients and robust standard errors for Baltimore Metropolitan Area watersheds

\begin{tabular}{|c|c|c|c|c|c|c|c|c|c|}
\hline & & $\begin{array}{l}\text { Drainage } \\
\text { area }\left(\mathrm{km}^{2}\right)\end{array}$ & $\begin{array}{l}\text { Pct } \\
\text { Dev }\end{array}$ & \multicolumn{3}{|c|}{ Linear Coefficient } & \multicolumn{3}{|c|}{$\begin{array}{l}\text { Non-linear } \\
\text { Coefficient }\end{array}$} \\
\hline $\begin{array}{l}\text { Station } \\
\text { ID }\end{array}$ & Name & & & Estimate & $\begin{array}{l}\text { Robust } \\
\text { Std err }\end{array}$ & & Estimate & $\begin{array}{l}\text { Robust } \\
\text { Std err }\end{array}$ & \\
\hline 1581500 & BYNUM RUN AT BEL AIR, MD & 21.7 & 65.96 & 0.537 & 0.07 & * & 1.045 & 0.19 & * \\
\hline 1581752 & PLUMTREE RUN NEAR BEL AIR, MD & 6.5 & 78.88 & 0.690 & 0.07 & * & 0.874 & 0.26 & * \\
\hline 1581757 & OTTER POINT CREEK NEAR EDGEWOOD, MD & 139 & 32.08 & 0.463 & 0.05 & * & 1.208 & 0.18 & * \\
\hline 1583600 & BEAVERDAM RUN AT COCKEYSVILLE, MD & 53.6 & 51.17 & 0.271 & 0.06 & * & 0.706 & 0.21 & * \\
\hline 1585090 & WHITEMARSH RUN NEAR FULLERTON, MD & 6.9 & 87.64 & 0.791 & 0.09 & * & 0.825 & 0.29 & * \\
\hline 1585100 & WHITEMARSH RUN AT WHITE MARSH, MD & 19.7 & 84.78 & 0.727 & 0.09 & * & 0.940 & 0.32 & * \\
\hline 1585104 & HONEYGO RUN NEAR WHITE MARSH, MD & 6.1 & 68.19 & 0.623 & 0.10 & * & 0.988 & 0.30 & * \\
\hline 1585200 & WEST BRANCH HERRING RUN AT IDLEWYLDE, MD & 6 & 86.64 & 0.817 & 0.08 & * & 0.304 & 0.27 & \\
\hline 1589100 & EAST BRANCH HERBERT RUN AT ARBUTUS, MD & 6.4 & 91.3 & 0.930 & 0.14 & * & 0.030 & 0.58 & \\
\hline 1589197 & GWYNNS FALLS NEAR DELIGHT, MD & 10.6 & 78.43 & 0.730 & 0.10 & * & 0.424 & 0.41 & \\
\hline 1589290 & SCOTTS LEVEL BRANCH AT ROCKDALE, MD & 8.7 & 79.51 & 0.627 & 0.06 & * & 0.915 & 0.22 & * \\
\hline 1589300 & GWYNNS FALLS AT VILLA NOVA, MD & 84.5 & 65.79 & 0.561 & 0.06 & * & 1.001 & 0.16 & * \\
\hline 1589305 & POWDER MILL RUN NEAR LOCHEARN, MD & 9.2 & 89.08 & 0.848 & 0.07 & * & 0.428 & 0.24 & * \\
\hline 1589312 & $\begin{array}{l}\text { DEAD RUN NEAR CATONSVILLE, MD } \\
\text { TRIBUTARY TO DEAD RUN TRIBUTARY AT }\end{array}$ & 2 & 95.63 & 0.991 & 0.08 & * & 0.256 & 0.20 & \\
\hline 1589317 & WOODLAWN, MD & 1.2 & 96.87 & 1.000 & 0.08 & * & 0.302 & 0.20 & \\
\hline 1589330 & $\begin{array}{l}\text { DEAD RUN AT FRANKLINTOWN, MD } \\
\text { GWYNNS FALLS AT WASHINGTON BLVD AT }\end{array}$ & 14.2 & 95.2 & 0.969 & 0.09 & * & 0.502 & 0.25 & * \\
\hline 1589352 & BALTIMORE, MD & 159.1 & 75.72 & 0.624 & 0.05 & * & 0.720 & 0.18 & * \\
\hline 1589440 & JONES FALLS AT SORRENTO, MD & 65.1 & 33.9 & 0.403 & 0.05 & * & 1.010 & 0.22 & * \\
\hline 1589500 & $\begin{array}{l}\text { SAWMILL CREEK AT GLEN BURNIE, MD } \\
\text { SOUTH FORK JABEZ BRANCH AT MILLERSVILLE, }\end{array}$ & 12.6 & 66.55 & 0.446 & 0.06 & * & 0.563 & 0.24 & * \\
\hline 1589795 & MD & 2.5 & 35.6 & 0.213 & 0.08 & * & 1.769 & 0.27 & * \\
\hline 1593500 & LITTLE PATUXENT RIVER AT GUILFORD, MD & 98 & 58.66 & 0.445 & 0.04 & * & 1.010 & 0.22 & * \\
\hline 1594000 & LITTLE PATUXENT RIVER AT SAVAGE, MD & 254.4 & 37.02 & 0.468 & 0.07 & * & 0.589 & 0.26 & * \\
\hline 1594440 & PATUXENT RIVER NEAR BOWIE, MD http://mc.manus & $\begin{array}{l}906.6 \\
\text { tcentral.co }\end{array}$ & $\begin{array}{l}31.86 \\
\text { hyp }\end{array}$ & 0.387 & 0.08 & * & 0.541 & 0.32 & * \\
\hline
\end{tabular}




\begin{tabular}{|c|c|c|c|c|c|c|c|c|c|c|}
\hline 1 & 1594526 & WESTERN BRANCH AT UPPER MARLBORO, MD & 233.6 & 50.38 & 0.610 & 0.05 & * & 0.661 & 0.18 & * \\
\hline 2 & 1644280 & BROAD RUN NEAR LEESBURG, VA & 196.9 & 56.03 & 0.299 & 0.11 & * & 0.520 & 0.61 & \\
\hline 3 & & LITTLE SENECA CREEK TRIBUTARY NEAR & & & & & & & & \\
\hline $\begin{array}{l}4 \\
5\end{array}$ & 1644375 & GERMANTOWN, MD & 3.3 & 82.65 & 0.625 & 0.09 & * & 0.527 & 0.38 & \\
\hline 6 & 1645000 & SENECA CREEK AT DAWSONVILLE, MD & 262.4 & 36.92 & 0.296 & 0.07 & * & -0.054 & 0.15 & \\
\hline 7 & 1646000 & DIFFICULT RUN NEAR GREAT FALLS, VA & 149.9 & 50.53 & 0.623 & 0.09 & * & 0.280 & 0.40 & \\
\hline $\begin{array}{l}0 \\
9\end{array}$ & 1647850 & TURKEY BRANCH NEAR ROCKVILLE, MD & 7 & 88.48 & 0.968 & 0.13 & * & -0.114 & 0.54 & \\
\hline 10 & & ROCK CREEK AT SHERRILL DRIVE WASHINGTON, & & & & & & & & \\
\hline 11 & 1648000 & $\mathrm{DC}$ & 136.8 & 70.99 & 0.715 & 0.11 & * & -0.415 & 0.44 & \\
\hline $\begin{array}{l}12 \\
13\end{array}$ & 1649150 & PAINT BRANCH TRIBUTARY NEAR COLESVILLE, MD & 2.7 & 39.35 & 0.456 & 0.08 & * & 1.115 & 0.30 & * \\
\hline 14 & 1649190 & PAINT BRANCH NEAR COLLEGE PARK, MARYLAND & 34 & 57.34 & 0.483 & 0.09 & * & 0.351 & 0.36 & \\
\hline 15 & & NORTH EAST BRANCH ANACOSTIA RIVER AT & & & & & & & & \\
\hline $\begin{array}{l}10 \\
17\end{array}$ & 1649500 & RIVERDALE, MD & 188.1 & 62.92 & 0.567 & 0.08 & * & 0.644 & 0.28 & * \\
\hline 18 & & NW BRANCH ANACOSTIA RIVER NEAR & & & & & & & & \\
\hline 19 & 1650500 & COLESVILLE, MD & 54.8 & 48.29 & 0.665 & 0.11 & * & -0.010 & 0.46 & \\
\hline
\end{tabular}

\footnotetext{
$*$ indicates coefficient estimate is significant at the alpha $=0.05$ level .
} 
TABLE 2. Results of logistic regression of percent undeveloped land and other controls on probability of VSA-type response

MODEL1B: Undeveloped Land + Morphologic and Meteorological

MODEL 1A: Undeveloped Land

: National Datase

$(n=91)$

\section{Undeveloped Land (\%)}

Total Impervious Area (\%) Developed Open Space (\%) Distance to CSO (m) Ret/Det SW Infrastructure (binary)

Average Slope (\%)

Average Annual Precipitation (cm/yr)

Catchment Area $\left(\mathrm{km}^{2}\right)$

Intercept

McFadden's R ${ }^{2}$

$0.516 \quad 67.566$

Count-based R2 (above mean)

0.038

0.560

\section{Panel B: BMA Dataset}

$(n=34)^{(b)}$
MODEL1C: Undeveloped Land +

Development Characteristics + Controls

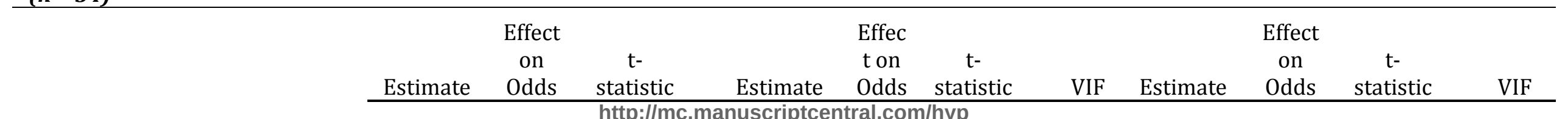




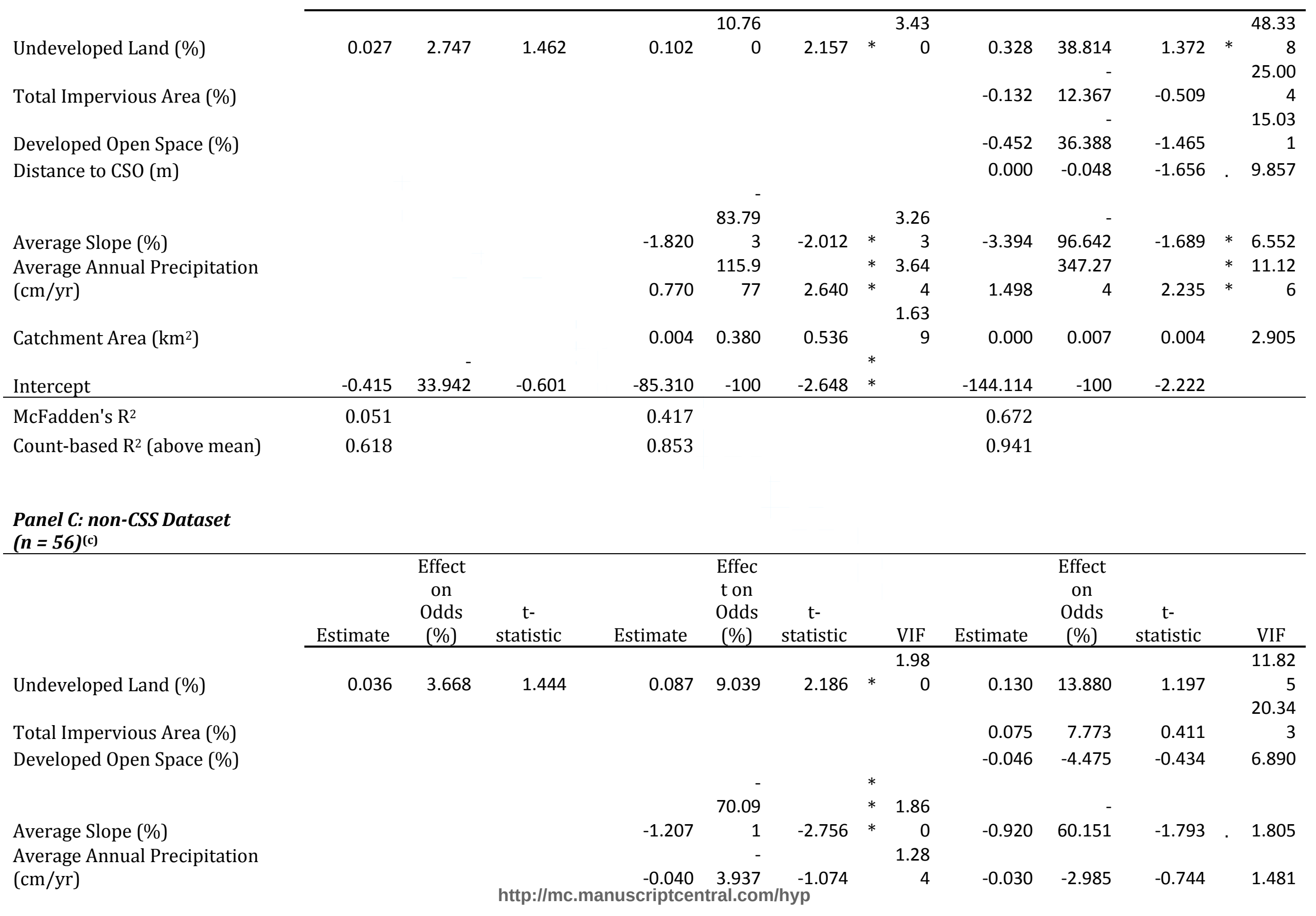




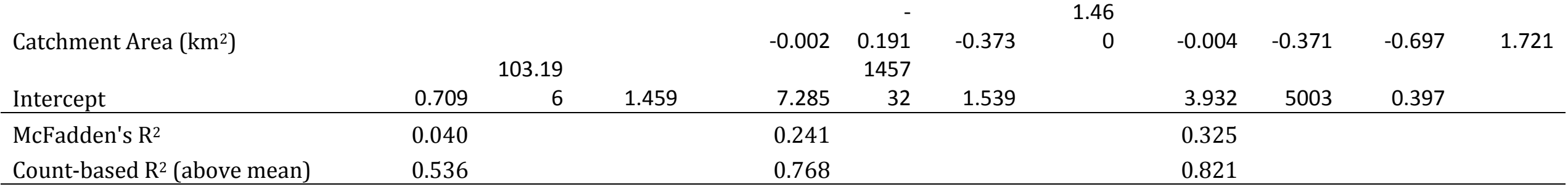

(a) . Significance at the 0.10 level ; * Significance at the 0.05 level; ${ }^{* *}$ Significance at the 0.01 level

(b) Retention/Detention stormwater infrastructure excluded because all BMA watersheds located in counties with detention, retention or infiltration-based infrastructure

(c) Distance to CSO and Ret/Det stormwater infrastructure effects could not be estimated due to complete separation in the data 
Table 3. Results of logistic regression of development types and other controls on probability of VSA-type response

MODEL2C: TIA + Open Space +

Other Development

MODEL 2A: TIA

MODEL2B: TIA + Open Space

Characteristics

\section{Panel A: National Dataset}

( $n=91)$

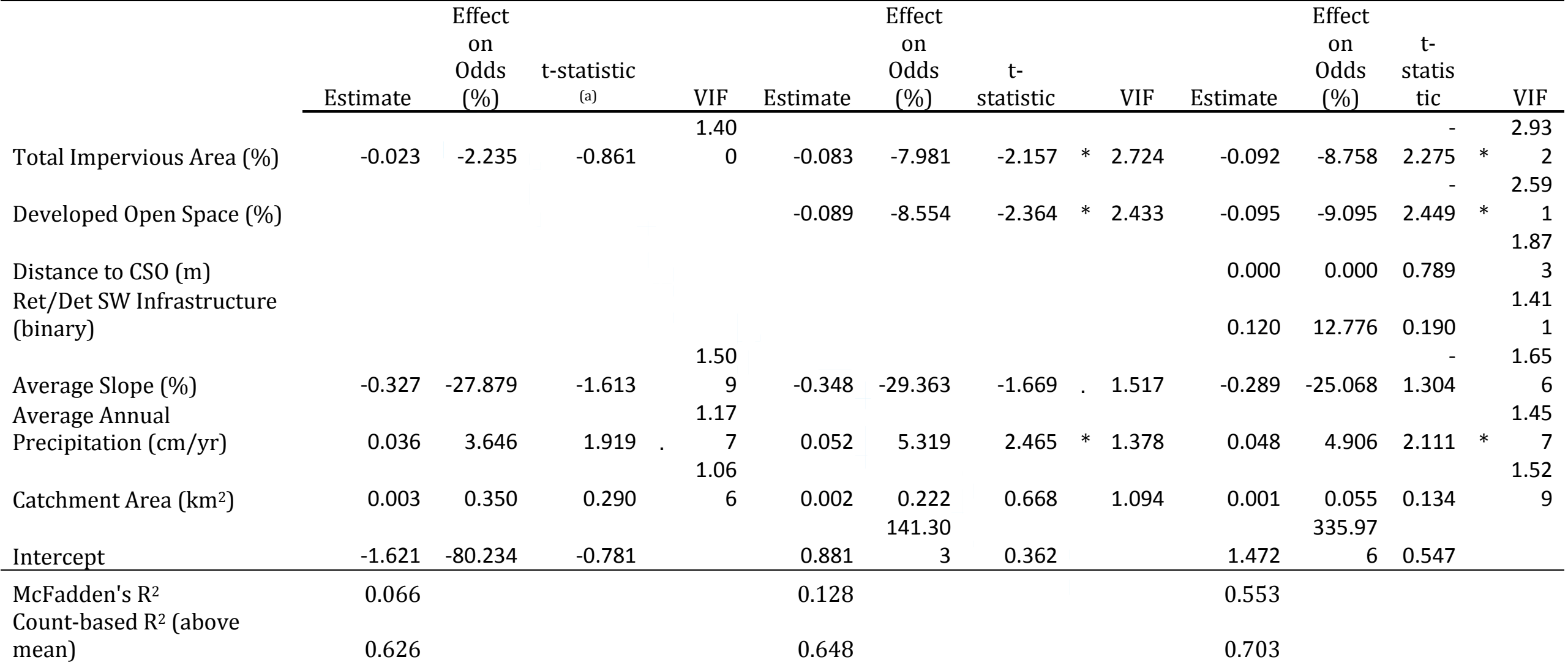

\section{Panel B: BMA Dataset}

$(n=34)^{(b)}$

\begin{tabular}{|c|c|c|c|c|c|c|c|c|c|c|c|c|}
\hline & Estimate & $\begin{array}{c}\text { Effect } \\
\text { on } \\
\text { Odds } \\
(\%)\end{array}$ & t-statistic & VIF & Estimate & $\begin{array}{c}\text { Effect } \\
\text { on } \\
\text { Odds } \\
(\%)\end{array}$ & $\begin{array}{c}\mathrm{t}- \\
\text { statistic }\end{array}$ & VIF & Estimate & $\begin{array}{c}\text { Effect } \\
\text { on } \\
\text { Odds } \\
(\%)\end{array}$ & $\begin{array}{c}\mathrm{t}- \\
\text { statis } \\
\text { tic }\end{array}$ & VIF \\
\hline Total Impervious Area (\%) & -0.117 & -11.081 & $\begin{array}{c}-2.052 \\
\text { http:/ }\end{array}$ & c.mar & $\begin{array}{l}-0.197 \\
\text { criptcentr }\end{array}$ & $\begin{array}{l}-17.855 \\
\text { com/hyp }\end{array}$ & -2.154 & * 4.617 & -0.438 & -35.489 & 2.160 & $\begin{array}{r}14.0 \\
* \quad 01\end{array}$ \\
\hline
\end{tabular}




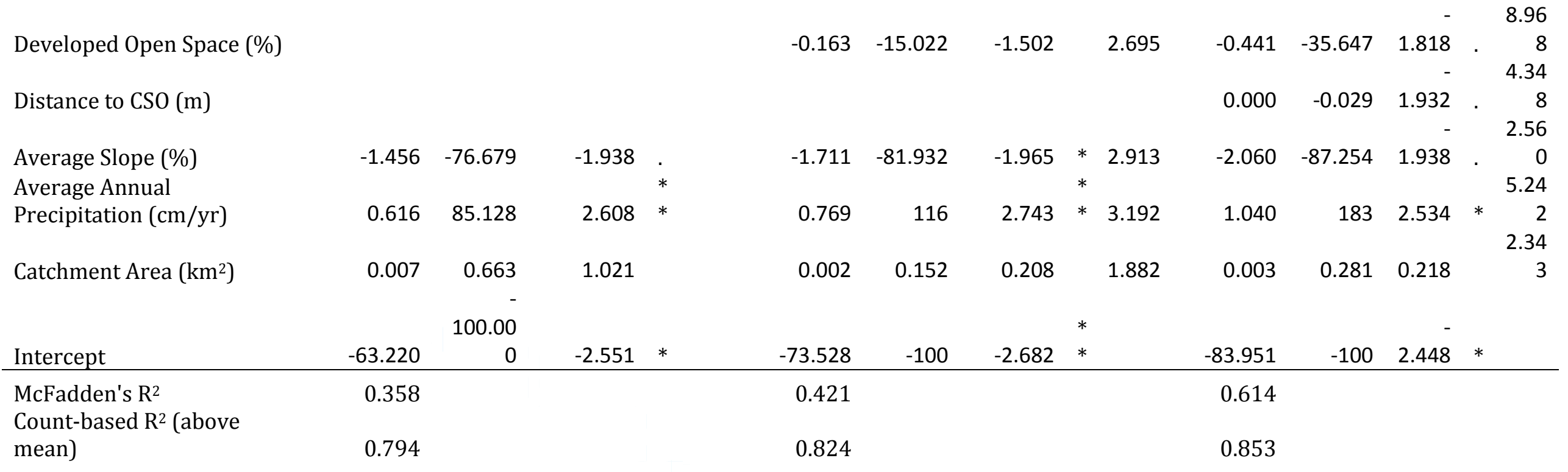

\section{Panel C: non-CSS Dataset}

$(n=56)^{(c)}$

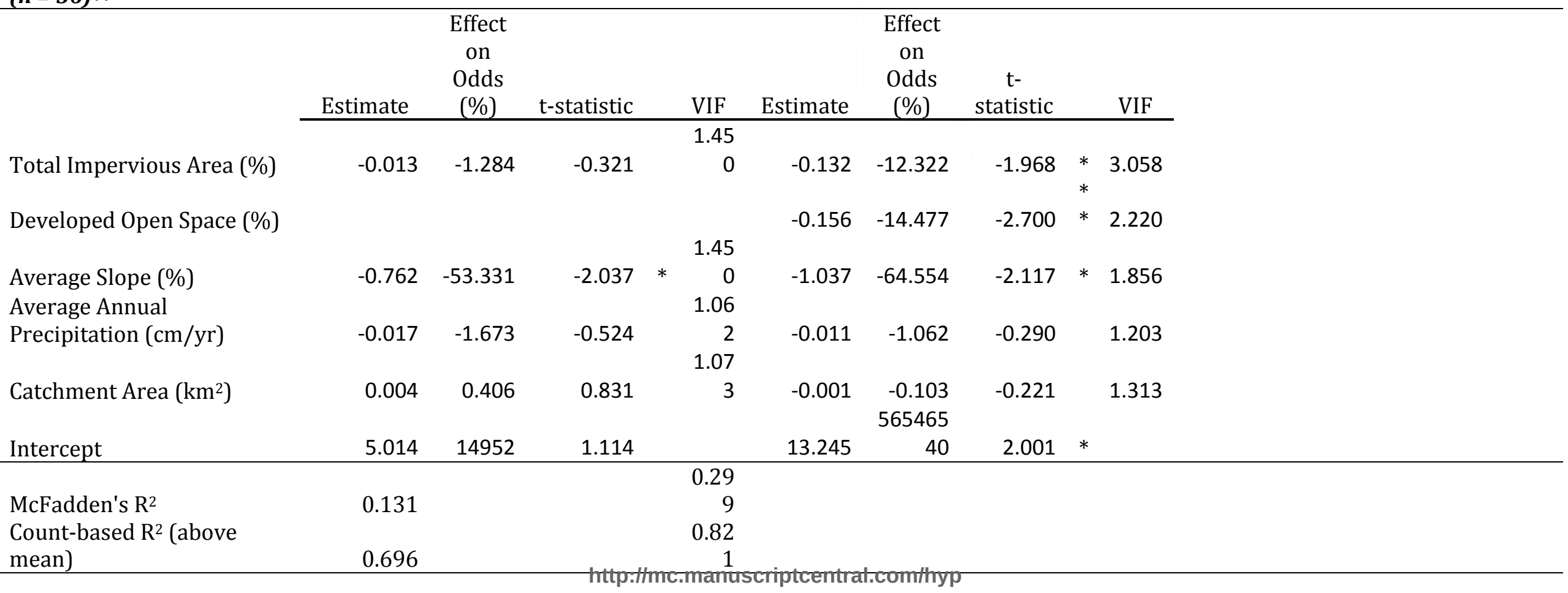


1 (a). Significance at the 0.10 level ; * Significance at the 0.05 level; ** Significance at the 0.01 level

(b) Retention/Detention stormwater infrastructure excluded because all BMA watersheds located in counties with detention, retention or infiltration-based infrastructure

(c) Distance to CSO and Ret/Det stormwater infrastructure effects could not be estimated due to complete separation in the data 